Article

\title{
Sustainability Assessment of Agricultural Systems in Paraguay: A Comparative Study Using FAO's SAFA Framework
}

\author{
Alice Soldi ${ }^{1}$, Maria José Aparicio Meza ${ }^{2}$, Marianna Guareschi ${ }^{3, *}$, Michele Donati ${ }^{1, *}$ and \\ Amado Insfrán Ortiz ${ }^{2}$ \\ 1 Dipartimento di Scienze Chimiche, della Vita e della Sostenibilità Ambientale, \\ Università degli Studi di Parma, Parco Area delle Scienze, 11/A, 43124 Parma (PR), Italy \\ 2 Facultad de Ciencias Agrarias, Universidad Nacional de Asunción, Campus Universitario, \\ Avda. Mariscal López, km 10, San Lorenzo 2160, Paraguay \\ 3 Dipartimento di Scienze Economiche e Aziendali, Università degli Studi di Parma, Via Kennedy, 6, \\ 43125 Parma (PR), Italy \\ * Correspondence: mariguare@gmail.com (M.G.); michele.donati@unipr.it (M.D.)
}

Received: 31 May 2019; Accepted: 3 July 2019; Published: 9 July 2019

\begin{abstract}
Sustainability is a topic that is at the center of current discussions in the political, economic, social, and environmental fields. For its analysis, an integral and multidisciplinary vision is needed. This work aims to assess the sustainability of agricultural systems in Paraguay through a comparison applying SAFA (Sustainability Assessment of Food and Agriculture Systems) indicators. The research focuses on 15 case studies on the territory of the Eastern Region of Paraguay divided into five classes of agricultural systems: agribusiness, conventional peasant family farming, agroecological peasant family farming, neo-rural farming, and indigenous agriculture. Data were collected through interviews with producers and key informants, direct observation, and scientific literature research in order to assess, through the SAFA Tool Software, the level of sustainability of each agricultural system as a whole and for each sustainability dimension (political, environmental, economic, and social dimension) in a comparative way. It has emerged that producers belonging to conventional peasant family farming, agroecological peasant family farming, neo-rural farming, and indigenous agriculture have achieved levels of sustainability that are similar to each other and very good in all four dimensions of sustainability. Meanwhile, agribusiness achieved moderate scores in the dimensions of governance and environmental integrity, and was good in the economic and social dimension.
\end{abstract}

Keywords: sustainability; agricultural systems in Paraguay; FAO's SAFA framework

\section{Introduction}

The growing human needs, together with economic activities, which exert increasing pressure on the Earth's resources, have led to the awareness of environmental problems generated by lifestyles that are incompatible with the regeneration process of the environment [1]. Sustainability is a fundamental theme of the present society and constitutes the cornerstone of the Sustainable Development Goals (SDG) [2], which were adopted by all United Nations Member States in 2015 and valid until 2030, which provide a shared program of peace and prosperity for people and the planet, for the present and the future. The 17 Sustainable Development Goals are an urgent call for action by all countries in a global partnership as they recognize that ending poverty and other deprivations must go hand in hand with strategies that improve health and education, reduce inequalities, and stimulate economic growth, while tackling climate change and working to preserve the oceans and forests. The objective of sustainable development is to improve people's quality of life without exploiting natural resources 
beyond the capacities provided by the environment [3]. In general, the sustainable development model can be defined as a series of proposals based on environmental sustainability, social justice, and democracy [4]. Although agriculture continues to be the engine of development in the 21st century, it faces new challenges such as the degradation of natural resources, climate change, free trade, and the development of new technologies [5]. The current agricultural production model, which in many areas and production systems is inherited from the Green Revolution, is based on the industrialization of natural resources and exports, and is a situation that promotes the growth of monoculture, genetically modified products, soil degradation, loss of biodiversity, intensive use of agrochemicals, a consequent increase in rural poverty, and a decrease in traditional agriculture [6]. New strategies are emerging that pursue a sustainable development of agricultural production means, with more environmentalist tendencies presenting the need to change the dominant model of agricultural production [7]. In order for agriculture to be sustainable, it must be sufficiently productive, economically viable, culturally and socially acceptable and ecologically adequate; that is, it needs to conserve natural resources and preserve the integrity of the environment such as the ecological diversity and the capacity of the agroecosystem to self-maintain [8]. Sustainable agriculture preserves diversity, improves soil resources, protects waterways, provides healthy food, reduces the producer's dependence on external sources, and grants a reliable source of income for farmers [9]. Technological advances in agriculture have allowed farmers to cultivate more land with less labor, and one of the main consequences of the increase in the mechanization of the agricultural system is that there are fewer job opportunities on farms, pushing many families to move to urban centers, leaving rural communities to decline, which are the custodians of agricultural traditions and natural resources [10].

Resilience goes hand in hand with sustainability: a complex ecosystem is characterized by a high degree of diversity and resists disturbances without significant structural and functional changes [11-13]. However, in addition to biophysical diversity, another characteristic that makes agroecosystems resilient is the knowledge diversity and the possibility of choice of the production system by farmers [14].

Agroecology is considered the scientific basis of sustainable agriculture, as it integrates traditional knowledge with modern knowledge to obtain production methods that respect the environment and society, in order to achieve not only production goals, but also the social equality and ecological sustainability of the agroecosystem [15-17]. In that sense, we consider agroecology in its normative sense, including its socio-economical, cultural, and political dimensions [17].

The approach to measuring sustainability changes according to the objectives of the study and the geographical scale. In any case, the use of indicators is useful for assessing the degree of achievement of the sustainability of an agroecosystem [8]. The sustainability indicators make perceivable a phenomenon that is not immediately and easily detectable, and allow us to understand the sustainability status of an agroecosystem or the critical aspects that endanger it [18]. A good indicator provides useful and important information on how the system works, and is also objective, predictive, and easy to process and interpret [8,19-22].

This paper aims to analyze the sustainability of the different agricultural systems in Paraguay by comparing them through the use of Sustainability Assessment of Food and Agriculture systems (SAFA) indicators developed by the Food and Agriculture Organization of the United Nations (FAO). More specifically, the research objective is twofold: (1) evaluating the level of sustainability of each typology of Paraguayan farm for identifying the relative strengthens and weaknesses with regard to the different sustainability themes foreseen in SAFA indicators; and (2) identifying the critical issues for each farm typology through the analysis of SAFA indicators and providing strategies for improving sustainability in Paraguayan agriculture.

The Paraguayan context was chosen as it is a country whose economy is mainly based on agriculture. Rural poverty, unequal land distribution (Gini coefficient of 0.93, as stated in the Agricultural Census 2008), increasing concentration of land in foreign companies (according to the Centro Paraguayo de Estudios Sociológicos, 25\% of the agricultural area is of foreign ownership) and 
the growing expansion of large estates addressed to the cultivation of products for export, are the main factors of emigration of the peasant population toward urban centers or foreign countries. The massive use of technology, favored by the Green Revolution, including the use of hybrid or genetically modified seeds and agrochemical products, has caused the degradation of fertile lands, the loss of biodiversity and food sovereignty, the marginalization of traditional colonies, desertification, water pollution, and the gradual loss of native seeds [23,24].

The agricultural land managed by large and professional farms (i.e., the so-called "agribusiness") is cultivated for obtaining goods mainly for export, while the peasant and indigenous communities exploit land for ensuring the family or community food provision. In this latter case, (local) markets intervene for food products exceeding subsistence needs. The area dedicated to the production of soy, rice, sugar cane, wheat, maize and canola, which are the agricultural products that are part of agribusiness, has reached $94 \%$ of the area dedicated to agriculture in Paraguay, leaving $6 \%$ to peasant agriculture. Between 2002/2003 and 2013/2014, agribusiness expanded by $139 \%$ (from 2,300,000 to $5,500,000$ hectares), while peasant agriculture had a $50 \%$ decrease in the cultivated area, from 685,000 hectares in the period 2002/2003 to 339,000 hectares in 2013/2014 [25]. Thanks to the income from the production of electricity and exports of soy and meat, Paraguay's economy has grown on average by $5 \%$ on an annual basis over the last decade. However, despite good macroeconomic indicators, the poverty rate is $42.3 \%$ (2014) [26,27]. Nearly all $(90 \%)$ of the land is owned by about 12,000 large farms, while the remaining $10 \%$ is distributed among 280,000 small and medium-sized properties [28]. The unfavorable climatic conditions and the low agricultural commodity market prices are the main factors inducing peasant families to abandon farming activity for the more attractive economic sectors in the urban centers, so that agricultural biodiversity and local food production are reducing [29-31].

According to the literature [32-35] and the legislation of the Cono Sur's countries, the agricultural systems in Latin America can be classified as: agribusiness, peasant family farming, neo-rural agriculture, and indigenous agriculture. Although Paraguayan legislation does not provide a clear classification of the various types of agricultural systems, indigenous agriculture is generally included in public laws and policies regarding peasant family farming. In this respect, Paraguayan farms are classified in terms of agricultural land size [34,35]: family farming (up to 50 hectares), and agriculture of large producers (starting from 50 hectares). In addition to the cultivated land, the factors that make it possible to differentiate family farming from the agriculture of large producers are the use of the labor force, access to land and capital resources, the use of strategies, the generation of income, and the destination of the products [36].

The rest of this article is articulated as follows: the next section describes the research methodology adopted, followed by the results and discussion in Section 3; finally, Section 4 concludes and presents the main policy implications of the study.

\section{Materials and Methods}

\subsection{Sustainability Assessment of Food and Agriculture Systems (SAFA)}

The present research adopts the SAFA method for measuring the level of sustainability in Paraguayan agriculture. The SAFA method is peculiar for its wide range of sustainability dimensions, its global applicability to both large and small farms, and its ease of applicability. SAFA, which focuses mainly on agri-food and rural systems, was developed by the FAO (Food and Agriculture Organization of the United Nations) in 2012 with the aim of evaluating the degree of sustainability of agricultural holdings and providing private and public entities with a set of indicators that are useful for detecting issues and identifying solutions.

Some studies show a comparison between SAFA methodology and other tools to assess sustainability in agriculture [37-39]. Authors have underlined the wide range of topics measured by the SAFA methodology as a strong point, but at the same time, it can determine an excess of qualitative 
information. In particular, Gasso [37] supposed that generic approaches (such as SAFA) can be used to assess environmental sustainability, while economic and social dimensions should be evaluated also using more quantitative information. De Olde et al. [39] argued that generic approaches must necessarily be adapted to the evaluation context so that they can provide information of a certain relevance and reliability.

SAFA methodology is structured on the basis of different hierarchical levels: dimensions, themes, sub-themes, and indicators. The more general level includes four dimensions of sustainability: good governance, environmental integrity, economic resilience, and social well-being. At an intermediate level it comprises 21 sustainability themes, which were defined by 58 sub-themes. At a more specific level, each sub-theme includes various indicators, for a total of 116, which can be measured with a performance score on a scale from 1 to 5 [40]. On an increasing scale, in conjunction with a traffic light color code, sustainability practices are defined: unacceptable (red), limited (orange), moderate (yellow), good (light green), and best (dark green).

The recipients of a SAFA evaluation are small, medium, and large companies, organizations, and other stakeholders who participate in the agriculture, livestock, forestry, aquaculture, and fisheries sectors. This methodology is an effective means for agri-food businesses in order to assess the sustainability of the activities and identify the weaknesses that will need to be improved. It is also a useful tool for non-governmental organizations (NGOs) with the aim of monitoring the progress of projects, and for governments, investors, and policy makers to control sustainable development goals. The SAFA framework provides an international reference tool for assessing the sustainability performance of agri-food companies, and its purpose is to support the implementation of sustainable and effective management in the agri-food sector. The first step for a correct assessment of sustainability is to identify the objectives and aims of the study. The next step is to describe the assessed entity, including geographic, dimensional, and sectoral information, and its sphere of influence and impact. In terms of contextualization, it is important to draw up a list of themes and sub-themes that are relevant to the study, as well as make a contextualized evaluation of the selected indicators and a list of data sources. The selection phases of the themes and sub-themes allow specific changes to the scoreboard, in particular for small-scale producers due to the lack of existing data and the limited relevance of global indicators. The evaluator can omit some specific themes that are irrelevant to the context and avoid the use of performance-based indicators when the measurements are not accessible, and instead use practice-based indicators. In the next phase, the sustainability indicators are selected, and the tools, metrics, and standards for data collection are listed, determining the data quality level through the attribution of a score. The Accuracy Score evaluation can vary from 1 to 3, where 1 corresponds to Low quality data, 2 corresponds to Moderate quality data, and 3 corresponds to High quality data depending on whether the data is primary, secondary or derives from estimations.

The evaluation was conducted following the SAFA Guidelines version 3.0 [40], which are guidelines that describe the purposes, outline the procedures, and contain themes and sub-themes to carry out a sustainability assessment. The SAFA indicators were selected through the review of technical-scientific documents, which is an appropriate analysis that is in accordance with the objectives set by the research and the availability of information.

Taking into account the context of Paraguay and the availability of data, 94 SAFA indicators [41] were chosen, out of a total of 116, to conduct the sustainability assessment (see Table 1 for an overview of the SAFA themes included in the analysis). 
Table 1. Selected Sustainability Assessment of Food and Agriculture Systems (SAFA) indicators.

\begin{tabular}{|c|c|}
\hline Themes & Not Analyzed \\
\hline \multicolumn{2}{|c|}{ Sustainability Dimension G: GOOD GOVERNANCE } \\
\hline G1 Corporate Ethics & $\checkmark$ \\
\hline G2 Accountability & Not analyzed due to the low availability of data. \\
\hline G3 Participation & $\checkmark$ \\
\hline G4 Rule of Law & Not analyzed due to the low availability of data. \\
\hline G5 Holistic Management & Not analyzed due to the low availability of data. \\
\hline \multicolumn{2}{|c|}{ Sustainability Dimension E: ENVIRONMENTAL INTEGRITY } \\
\hline E1 Atmosphere & $\checkmark$ \\
\hline E2 Water & $\checkmark$ \\
\hline E3 Land & $\checkmark$ \\
\hline E4 Biodiversity & $\checkmark$ \\
\hline E5 Materials and Energy & $\checkmark$ \\
\hline E6 Animal Welfare & $\begin{array}{l}\text { This theme has not been analyzed since not all the farms taken } \\
\text { into consideration breed animals. }\end{array}$ \\
\hline \multicolumn{2}{|c|}{ Sustainability Dimension C: ECONOMIC RESILIENCE } \\
\hline C1 Investment & $\checkmark$ \\
\hline C2 Vulnerability & $\checkmark$ \\
\hline C3 Product Quality and Information & $\begin{array}{l}\text { This theme has not been considered since in most cases, the } \\
\text { products are sold in their natural state, so there are no } \\
\text { processing, labeling and traceability systems. }\end{array}$ \\
\hline C4 Local Economy & $\checkmark$ \\
\hline \multicolumn{2}{|c|}{ Sustainability Dimension S: SOCIAL WELL-BEING } \\
\hline S1 Decent Livelihood & $\checkmark$ \\
\hline S2 Fair Trading Practices & $\checkmark$ \\
\hline S3 Labour Rights & $\checkmark$ \\
\hline S4 Equity & $\checkmark$ \\
\hline S5 Human Safety and Health & $\checkmark$ \\
\hline S6 Cultural Diversity & $\checkmark$ \\
\hline
\end{tabular}

Source: authors' elaboration on SAFA indicators.

Once the indicators have been selected, the data have been processed with the SAFA Tool Software (version 2.2.40) [42], which allows a graphical representation of the results to be obtained and provides a complete report on performance, including issues and data quality. The final report should identify areas that need improvement and those with good levels of sustainability. The display of sustainability performance is represented by a radar chart in which a black line connects the various themes analyzed following a traffic light color code: very good/good practices (green), need for improvement (yellow/orange), or unacceptable (red).

\subsection{Selection of Agricultural Systems, Area, and Case Studies}

The classification of agricultural systems in Paraguay (Table 2) and the selection of farms (Table 3) was carried out by reviewing legislation and literature, field experience, and consultation and collaboration with relevant experts in the agri-food system of Paraguay and internationals such as Carrera de Ingeniería en Ecología Humana, Facultad de Ciencias Agrarias, Universidad Nacional de Asunción; the delegates of the Ministry of Agriculture and Livestock of Piribebuy; Red Agroecologica 
of Asunción; APRO (Association of Organic Producers); Rural Association of Youth of Paraguay; and researchers at the NITA Universidad Federal do Paraná group.

Table 2. Classification of agricultural systems in Paraguay in the present study (adapted from reference [32]).

\begin{tabular}{lcc}
\hline & Agricultural System & Number of Farms Analyzed \\
\hline & Agribusiness & 3 \\
& Agro-ecological peasant family farming & 3 \\
Peasant family farming and & Conventional peasant family farming & 3 \\
indigenous agriculture & Neo-rural agriculture & 3 \\
& Indigenous agriculture & 3 \\
\hline
\end{tabular}

Source: authors' elaboration.

Here we present the main and general characteristics, as found in the literature, of the agricultural systems taken into analysis that reflect the diversity of farm types in Paraguay.

Agribusiness is geared toward maximizing the rate of profit and capital accumulation. Its main features are the mechanization of agricultural land with the use of energy derived from fossil fuels, the transformation of ecosystems into large areas of genetically uniform monoculture, generally with extensions of more than 50 hectares, the reduction of biodiversity, the use of transgenic seeds, and the manipulation of natural components through the use of agrochemicals. Workers are hired by the owner; the role of family labor is weak or absent, and the products are destined for export [15,32].

Peasant family farming is based on small family businesses that are generally less than 10 hectares, and produce food for self-consumption and for markets of extreme proximity $[15,43]$. These companies use local resources, and human and animal strength are the main sources of energy [15]. Generally, a wide variety of species is cultivated that adapt to the characteristics of the area [44]. The work is based on family labor and exceptionally it is hired; the bonds within the community are very strong and based on solidarity, such as the "minga", which is a practice based on reciprocity that consists of the exchange of working hours and favors in the productive activity $[32,45,46]$.

The so-called neo-farmers [47], neo-peasants [48], or back-to-the-landers are migrants from cities to rural areas who seek to achieve an alternative lifestyle through farming activity and rural context $[49,50]$. New rural farmers look for a new model of agriculture that is more economically, socially, and environmentally sustainable, and can protect biodiversity and promote the quality local food [51].

Indigenous agriculture is based on traditional production systems with the conservation of natural resources in order to produce food for their subsistence with family labor [52]. In indigenous communities, men dedicate themselves to hunting, fishing, and land preparation, while women are involved in sowing, harvesting, processing food, and economically administering the family. Work is communal, and land ownership is collective [53].

Finally, we identified and selected three farms for each system analyzed, for a total of 15 farms (Table 3), in order to reflect the diversity of farm types in the Paraguayan context. For each type of agricultural system taken into consideration, it was found that the characteristics of the farms were similar, thus justifying the limited number of case studies that are analyzed. The study focused (Figure 1) on the Central and Cordillera departments, which consist of the most densely populated area of Paraguay. In order to study agribusiness, areas were selected in the departments of Cordillera, Misiones, and Concepción, where there is a high availability of land for agricultural purposes. As regards neo-rural agriculture, cases have been taken into consideration both in semi-urban areas, in the Central Department, and in rural areas, in the Itapúa Department. In order to analyze indigenous agriculture, it was necessary to move to the Amambay region, on the border with Brazil. The region of Chaco, or the Western Region, was not taken into consideration due to completely different ecosystems and weather conditions from the Eastern Region. 


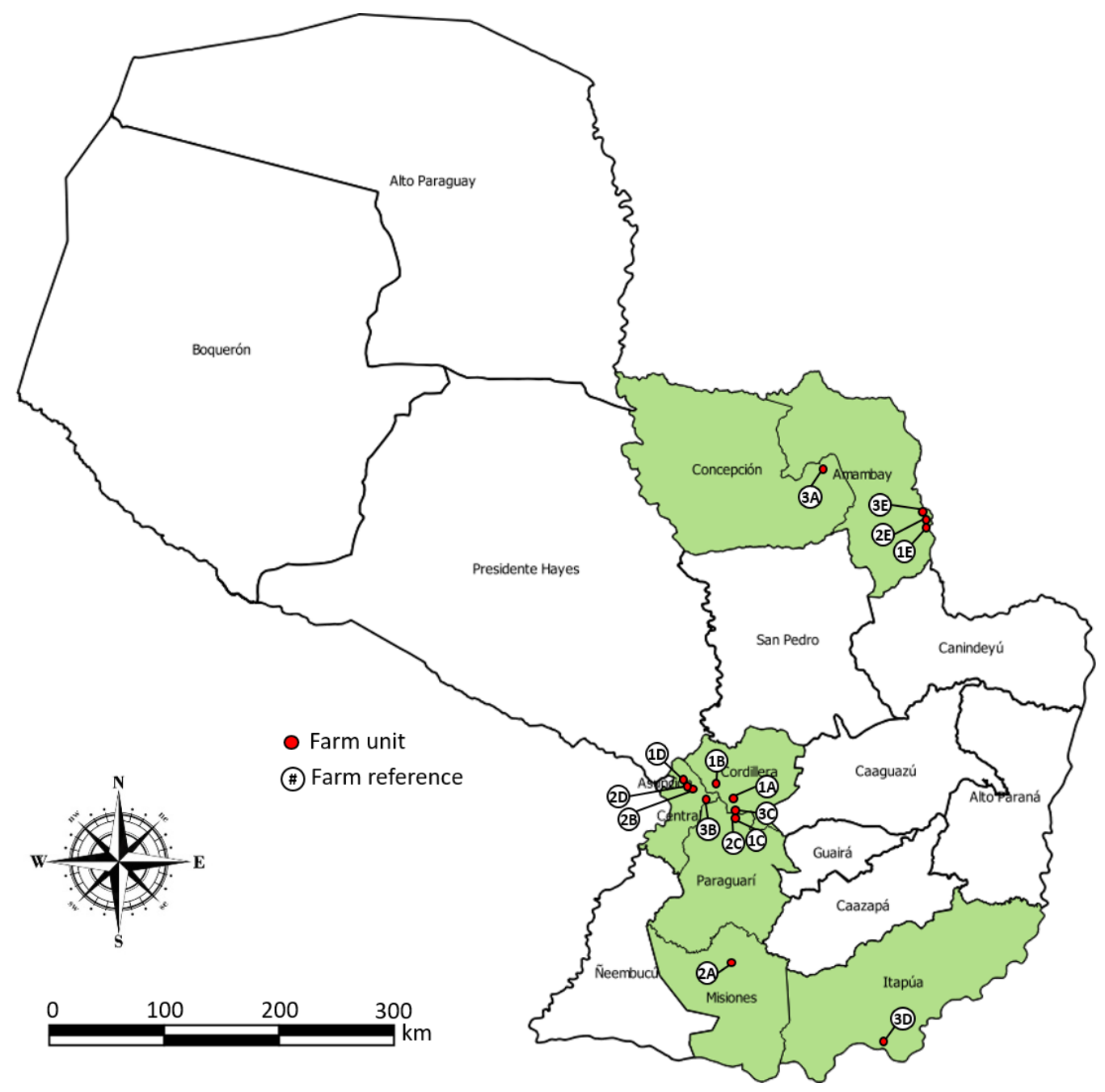

Figure 1. Study area.

Table 3. Overview of the selected farms.

\begin{tabular}{|c|c|c|c|c|c|c|}
\hline \multirow{2}{*}{$\begin{array}{l}\text { Analyzed } \\
\text { Farm }\end{array}$} & \multirow{2}{*}{ Location } & \multirow{2}{*}{$\begin{array}{l}\text { Extension } \\
\text { (ha) }\end{array}$} & \multirow{2}{*}{ Crop } & \multirow{2}{*}{ Livestock } & \multirow{2}{*}{$\begin{array}{c}\text { Employees } \\
\text { No. }\end{array}$} & \multirow{2}{*}{$\begin{array}{c}\text { Family } \\
\text { No. }\end{array}$} \\
\hline & & & & & & \\
\hline \multicolumn{7}{|c|}{ Agribusiness } \\
\hline $1 \mathrm{~A}$ & Piribebuy & 900 & sugar cane & - & 200 & 0 \\
\hline $2 \mathrm{~A}$ & $\begin{array}{l}\text { San Juan } \\
\text { Bautista }\end{array}$ & 6 & rice & - & $\begin{array}{c}10 \\
\text { permanent } / 100 \\
\text { casual }\end{array}$ & 0 \\
\hline $3 \mathrm{~A}$ & Yby Yau & 4 & soy and corn & Cattle & 4 & 1 \\
\hline \multicolumn{7}{|c|}{ Agroecological peasant family farming } \\
\hline 1B & Altos & 80 & $\begin{array}{c}\text { Cassava, beans, corn, } \\
\text { potatoes, tomatoes, } \\
\text { peppers, oranges, } \\
\text { grapefruit, cucumbers, } \\
\text { pumpkins, papaya, } \\
\text { maracuja }\end{array}$ & $\begin{array}{c}\text { Cattle, pigs, } \\
\text { hens }\end{array}$ & 0 & 10 \\
\hline
\end{tabular}


Table 3. Cont.

\begin{tabular}{|c|c|c|c|c|c|c|}
\hline \multirow{2}{*}{$\begin{array}{l}\text { Analyzed } \\
\text { Farm }\end{array}$} & \multirow{2}{*}{ Location } & \multirow{2}{*}{$\begin{array}{l}\text { Extension } \\
\text { (ha) }\end{array}$} & \multirow{2}{*}{ Crop } & \multirow{2}{*}{ Livestock } & \multirow{2}{*}{$\begin{array}{c}\text { Employees } \\
\text { No. }\end{array}$} & \multirow{2}{*}{$\begin{array}{c}\text { Family } \\
\text { No. }\end{array}$} \\
\hline & & & & & & \\
\hline $2 \mathrm{~B}$ & Itauguá & 5 & $\begin{array}{l}\text { Cucumbers, lettuce, mango, } \\
\text { mandarins, oranges, } \\
\text { eggplants, tomatoes, } \\
\text { cassava, peppers, } \\
\text { courgettes, carrots, rocket, } \\
\text { and bananas. }\end{array}$ & Cattle, hens & 4 & 1 \\
\hline $3 \mathrm{~B}$ & Ypacarai & 10 & $\begin{array}{l}\text { Tomatoes, peppers, corn, } \\
\text { cassava, lettuce, beans }\end{array}$ & Cattle, hens & 0 & 1 \\
\hline \multicolumn{7}{|c|}{ Conventional peasant family farming } \\
\hline $1 \mathrm{C}$ & Piribebuy & 0.75 & $\begin{array}{l}\text { Tomatoes, peppers, corn, } \\
\text { cassava, beans (for selling); } \\
\text { fruit, pumpkins, nuts, } \\
\text { aromatic herbs, onions (for } \\
\text { self-consumption) }\end{array}$ & Pigs, hens & $\begin{array}{l}\text { temporary } \\
\text { employed if } \\
\text { necessary }\end{array}$ & 1 \\
\hline $2 \mathrm{C}$ & Chololó & 0.12 & $\begin{array}{l}\text { Peppers (for selling); } \\
\text { cucumbers, lettuce, } \\
\text { tomatoes, parsley, onions } \\
\text { (for self-consumption) }\end{array}$ & - & 0 & 1 \\
\hline $3 C$ & Piribebuy & 4 & $\begin{array}{l}\text { Cassava, corn, beans, } \\
\text { origan, sorghum }\end{array}$ & $\begin{array}{l}\text { Cattle, pigs, } \\
\text { hens }\end{array}$ & $\begin{array}{l}\text { temporary } \\
\text { employed if } \\
\text { necessary }\end{array}$ & 1 \\
\hline \multicolumn{7}{|c|}{ Neo-rural agriculture } \\
\hline $1 \mathrm{D}$ & Luque & 1 & $\begin{array}{l}\text { Lettuce, bananas, parsley, } \\
\text { rocket, carrots tomatoes, } \\
\text { lemons, papaya. }\end{array}$ & Pigs, hens & 2 & 1 \\
\hline $2 \mathrm{D}$ & Aregua & 10 & $\begin{array}{c}\text { Carrots, peppers, lattuce, } \\
\text { eggplants, cabbage, persley, } \\
\text { rocket, basil, sugar cane, } \\
\text { soy, garlic, spinach, } \\
\text { potatoes, corn, tomatoes, } \\
\text { beet, chili pepper, onion, } \\
\text { strawberries, papaya, } \\
\text { maracujá. }\end{array}$ & Pigs & $\begin{array}{c}2 \text { and several } \\
\text { volunteers }\end{array}$ & 1 \\
\hline $3 \mathrm{D}$ & $\begin{array}{l}\text { Encarna- } \\
\text { ción }\end{array}$ & 5 & $\begin{array}{l}\text { Carrots, peppers, tomatoes, } \\
\text { rocket, basil, cabbage, } \\
\text { beans, chili peppers. }\end{array}$ & - & 3 & 1 \\
\hline \multicolumn{7}{|c|}{ Indigenous agriculture } \\
\hline $1 \mathrm{E}$ & $\begin{array}{l}\text { Capitan } \\
\text { Bado }\end{array}$ & 2 & \multirow{3}{*}{$\begin{array}{l}\text { Oats, corn, beans, cassava, } \\
\text { peanuts, potatoes, } \\
\text { pumpkins, rice, lettuce, } \\
\text { tomatoes, carrots, chickpeas, } \\
\text { zucchini, beets, lentils, } \\
\text { watermelons, honey, mate } \\
\text { grass and medicinal herbs. }\end{array}$} & \multirow{3}{*}{$\begin{array}{l}\text { Domestic } \\
\text { and } \\
\text { woodland } \\
\text { animals }\end{array}$} & 0 & $\begin{array}{c}400 \\
\text { people }\end{array}$ \\
\hline $2 \mathrm{E}$ & $\begin{array}{l}\text { Capitan } \\
\text { Bado }\end{array}$ & 1 & & & 0 & $\begin{array}{c}100 \\
\text { people }\end{array}$ \\
\hline $3 \mathrm{E}$ & $\begin{array}{l}\text { Capitan } \\
\text { Bado }\end{array}$ & 500 & & & 0 & $\begin{array}{l}350 \\
\text { people }\end{array}$ \\
\hline
\end{tabular}

Source: authors' elaboration.

\subsection{Data Collection}

Data were collected between May and December 2018 through interviews, direct observation, and literature review.

Primary information was obtained through:

- Semi-structured interviews: conducted in the selected farms, lasting between 35-100 min aimed at answering a series of questions based on the SAFA indicators [52]. The principal investigator 
interviewed each representative of the case studies that were taken into consideration, except for the three cases of indigenous agriculture, where a single interview was addressed to a key informant. The questions have been translated from English into Spanish, and the interviews have been transcribed in the original language.

- Direct observation: of farms taking into account the indicators to be analyzed. Visits and direct observations were made in all the farms involved in the study, with the exception of the 3A, $1 \mathrm{~B}$, and indigenous communities due to the impossibility of visiting the area without a Guaraní speaking guide and being accepted by the communities.

Secondary information was obtained through:

- Documents and literature review in order to integrate the data and concepts that give scientific support to the work. Paraguayan laws and regulations, official documents such as agricultural censuses, specialized literature, technical documents of organizations working in the national and international sector, and academic and scientific texts were taken into consideration.

\section{Results and Discussion}

\subsection{Evaluation of the Sustainability Level of Agricultural Systems in a Comparative Way for Each Agricultural System}

This paragraph provides a comparison of the tree analyzed farms for each agricultural system according to the SAFA radar chart, including some detailed information for each case study.

\subsubsection{Agribusiness}

The results obtained by the three farms are very variable between them, and are included between limited and good levels of sustainability (Figure 2 and Table 4). The themes in which the three farms have achieved the same levels of sustainability are: "Biodiversity", in which the three companies have reached a limited level as they cultivate large-scale monocultures; "Vulnerability", with a good score thus being not very vulnerable, since they adopt strategies to mitigate internal and external risks; "Local Economy", with good levels of sustainability as the companies support the local economy by employing local labor.

There are differences that are sometimes marked between the levels of sustainability achieved by the three farms in the following themes: in "Corporate Ethics", 1A has reached a good level, as the company tends toward sustainable practices; $2 \mathrm{~A}$ and 3A have achieved a limited level, since their mission is not focused on sustainable development but on maximizing production. Regarding the theme "Atmosphere", 1A and 3A have reached moderate levels and 2A is limited, as they use machinery with consequent emissions of greenhouse gases and a use of chemicals that can interfere with the air quality. In the theme Water, $1 \mathrm{~A}$ has obtained a good score, as it is totally dependent on rainfall, $3 \mathrm{~A}$ obtained a moderate score because it uses chemical substances that can interfere with water quality, and 2A obtained a limited score, since the water is taken in abundance from the neighboring water bodies to irrigate the rice plantation. In "Materials and Energy" $1 \mathrm{~A}$ has achieved good levels of sustainability as it recycles materials. In "Investment", 1A has reached a good level of sustainability, because it invests in sustainability in the long term, introducing sustainable practice in agriculture in its experimental fields to reduce chemical inputs. In "Decent Livelihood", 1A has reached moderate levels, since the work shifts are heavy, leaving few times for rest; finally, in "Labor Rights", 1A obtained a moderate score, because the workers do not have a regular contract where they are paid for the day, in addition to the company hindering trade union struggles and penalizing those who seek to claim their rights, while $2 \mathrm{~A}$ and $3 \mathrm{~A}$ have reached good levels because working conditions are not heavy, and most employees have regular contract. 
Table 4. Agribusiness interview information.

\begin{tabular}{|c|c|}
\hline \multicolumn{2}{|r|}{ Agribusiness } \\
\hline \multicolumn{2}{|r|}{ Good Governance } \\
\hline Corporate Ethics & $\begin{array}{l}\text { The company's mission is not focused on sustainable development, but rather } \\
\text { on maximizing the production. }\end{array}$ \\
\hline Participation & $\begin{array}{l}\text { Difficult identification and participation of all stakeholders, since the work is } \\
\text { entrusted to third parties. }\end{array}$ \\
\hline \multicolumn{2}{|r|}{ Environmental Integrity } \\
\hline Atmosphere & Use of machinery and chemicals. \\
\hline Water & $\begin{array}{l}\text { In } 1 \mathrm{~A} \text { and } 3 \mathrm{~A} \text {, the crops are not irrigated. } \\
\text { In } 2 \mathrm{~A} \text {, the water is taken in abundance from neighboring water bodies in order } \\
\text { to irrigate the plantation. }\end{array}$ \\
\hline Land & $\begin{array}{l}\text { 1A has organic and conventional cultivation. It does not use highly } \\
\text { contaminated chemicals and uses distillery residues to supply minerals to the } \\
\text { soil. } 120 \mathrm{t} / \text { ha yield. } \\
\text { Due to the exploitation of the soil, the yield of } 2 \mathrm{~A} \text { over the years has changed } \\
\text { from } 13 / 14 \text { to } 8 / 9 \mathrm{t} / \mathrm{ha} \text {. } \\
2 \mathrm{~A} \text { and } 3 \mathrm{~A} \text { use chemical fertilizers and pesticides, fumigating } 10 \text { times for } 2 \mathrm{~A} \\
\text { and eight times per cycle for } 3 \mathrm{~A} \text {. } \\
\text { 3A uses the sod-seeding technique, and seeds are treated with chemicals. } \\
\text { Soil analysis determined the amount of fertilizer to be used. } 1 \mathrm{~A} \text { leaves the land } \\
\text { one green manure crop every five years, while } 2 \mathrm{~A} \text { and } 3 \mathrm{~A} \text { never do. }\end{array}$ \\
\hline Biodiversity & $\begin{array}{l}\text { Large-scale monocultures. } \\
\text { 3A interchanges soy with corn at each cycle. }\end{array}$ \\
\hline Materials and Energy & $\begin{array}{l}\text { Material recycling. In all cases, cultivation is mechanized. } \\
\text { To prevent the deforestation of native plants for the use of timber, 1A own a } \\
\text { eucalyptus plantation, whose wood is used as combustible. }\end{array}$ \\
\hline \multicolumn{2}{|r|}{ Economic Resilience } \\
\hline Investment & Moderate long-term investment in experimentation for sustainable agriculture. \\
\hline Vulnerability & $\begin{array}{l}\text { Adoption of own strategies to mitigate internal and external risks, as they do } \\
\text { not have insurance. }\end{array}$ \\
\hline Local Economy & Production for export. Regional workforce. \\
\hline \multicolumn{2}{|r|}{ Social Well-Being } \\
\hline Decent Livelihood & $\begin{array}{l}\text { In } 1 \mathrm{~A} \text {, the work shifts are heavy, the workers earn minimum wage, and } \\
\text { overtime is not adequately paid. Refresher courses are organized for their } \\
\text { employees. In } 2 \mathrm{~A} \text { and } 3 \mathrm{~A} \text {, the work is not heavy. }\end{array}$ \\
\hline Fair Trading Practices & $\begin{array}{l}\text { In } 1 \mathrm{~A} \text {, the } 200 \text { daily workers in the plantation were paid for piecework and did } \\
\text { not have regular contracts. } \\
2 \mathrm{~A} \text { has } 10 \text { permanent workers and } 100 \text { casual workers. The permanent } \\
\text { employees have a regular contract, while the daily workers not. } \\
\text { 3A has four permanent workers with specific training. }\end{array}$ \\
\hline Labour Rights & $\begin{array}{l}\text { 1A hinders trade union struggles, penalizing those who seek to claim } \\
\text { their rights. }\end{array}$ \\
\hline Equity & 1A also employs women and disabled people according to social policies. \\
\hline Human Safety and Health & $\begin{array}{l}\text { Social and medical insurance only exists for permanent workers, such as } \\
\text { agronomists and machinery operators. }\end{array}$ \\
\hline Cultural Diversity & Use of modern knowledge and technology. \\
\hline
\end{tabular}




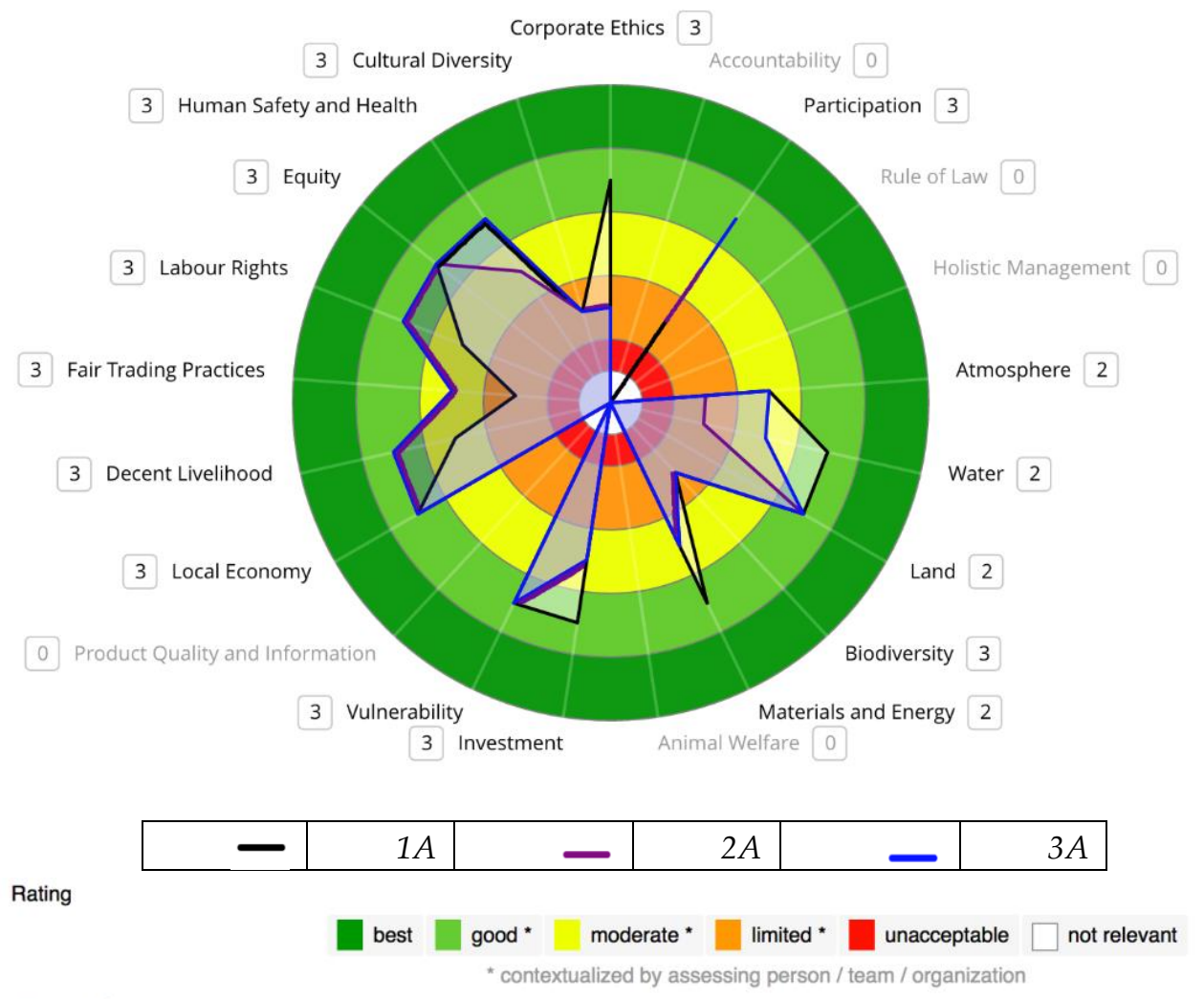

Accuracy Score

1 Low quality data 2 Moderate quality data 33 High quality data

Figure 2. Agribusiness SAFA radar chart.

\subsubsection{Agroecological Peasant Family Farming}

The results obtained by the three farms are very similar to each other, and are between good and very good levels of sustainability (Figure 3 and Table 5). The themes in which the three farms have achieved the same levels of sustainability are: Participation, in which the three companies have achieved a very good score as each member of the company makes its contribution to the community and takes part in the decision-making process; Atmosphere, Water, and Land, in which the levels achieved are very good, since they are agroecological producers and sustainable practices are adopted to preserve the atmosphere, water, and soil; "Biodiversity", in which farms have reached very good levels because a great variety of products is grown and farmyard animals are raised;" Materials and Energy", with very good levels of sustainability as the residues generated by agricultural work are recycled; "Investment", with very good levels, because the production is supervised by technicians and agronomists who successfully plan and manage the company; "Vulnerability", with good levels for which companies are not vulnerable, thanks to the great diversity of production and the various cultivation strategies; "Labor Rights", with very good scores because since it is a peasant family farming, there are no real "employee-employer" working links but rather solidarity ties between family members; "Equity", with good levels, because men and women take part in the production process; "Human Safety" and "Health and Cultural Diversity" with very good levels, because food sovereignty is guaranteed. 
Table 5. Agroecological peasant family farming interview information.

\begin{tabular}{|c|c|}
\hline \multicolumn{2}{|r|}{ Agroecological Peasant Family Farming } \\
\hline \multicolumn{2}{|r|}{ Good Governance } \\
\hline Corporate Ethics & $\begin{array}{l}\text { Company mission aims at sustainable practices through the application of the } \\
\text { principles of agroecology. }\end{array}$ \\
\hline Participation & $\begin{array}{l}\text { Each company member contributes to the community and takes part in the } \\
\text { decision-making process. }\end{array}$ \\
\hline \multicolumn{2}{|r|}{ Environmental Integrity } \\
\hline Atmosphere & No machinery is used; air quality is not affected. \\
\hline Water & $\begin{array}{l}\text { In } 1 \mathrm{~B} \text {, the crops are not irrigated. } \\
\text { In the absence of rain in } 2 \mathrm{~B} \text { and } 3 \mathrm{~B} \text {, the garden is irrigated every day through a } \\
\text { drip irrigation system and a sprinkler. The water is taken from an artesian well, } \\
\text { which everyone can use for two hours a day. } \\
\text { In all cases, part of the cultivation is protected from the sun by shading nets. }\end{array}$ \\
\hline Land & $\begin{array}{l}\text { Various techniques such as crop rotation, compost, manure, vegetation cover, } \\
\text { associated cultivation, legume green manure, synthetic fertilizers, and } \\
\text { biological pesticides are used. Aromatic plants and fruit trees act as a dividing } \\
\text { barrier between the various plots of land so that pests do not invade cultivation. } \\
\text { Plastic mulch is used to prevent weed growth, keep soil moisture, and protect } \\
\text { the soil from erosion. }\end{array}$ \\
\hline Biodiversity & $\begin{array}{l}\text { A wide variety of vegetables and fruits are cultivated. The farms also raise } \\
\text { cows, pigs, and chickens from which milk, cheese, meat, and eggs are obtained } \\
\text { for self-consumption. In addition to the land used for agriculture, there are } \\
\text { native woods, courses, and water springs. }\end{array}$ \\
\hline Materials and Energy & $\begin{array}{l}\text { The residues generated by agricultural work are reused. } \\
\text { The work is mainly manual. During the preparation of the soil, a small } \\
\text { mechanical plough is used in 2B, while 1B uses ox-drawn plows. }\end{array}$ \\
\hline \multicolumn{2}{|r|}{ Economic Resilience } \\
\hline Investment & $\begin{array}{l}\text { Production is supervised by technicians and agronomists who successfully plan } \\
\text { and manage the company. }\end{array}$ \\
\hline Vulnerability & Great diversity of production and various cultivation strategies. \\
\hline Local Economy & $\begin{array}{l}\text { The workforce is regional, and the cultivated products are destined for } \\
\text { self-consumption and for extremely close trade. }\end{array}$ \\
\hline \multicolumn{2}{|r|}{ Social Well-Being } \\
\hline Decent Livelihood & $\begin{array}{l}\text { Workers' rights are respected through appropriate working hours, leaving room } \\
\text { for rest, family, and home care. }\end{array}$ \\
\hline Fair Trading Practices & $\begin{array}{l}\text { The agricultural work is carried out by the members of the family, and when } \\
\text { necessary, occasional workers are hired; in } 2 \mathrm{~B} \text {, in addition to the family } \\
\text { members, four people from the area work permanently on the farm. }\end{array}$ \\
\hline Labour Rights & $\begin{array}{l}\text { There are no real "employee-employer" links, but there are solidarity ties } \\
\text { between family members. } \\
\text { Minga, mutual help in the garden, is practiced. } \\
\text { In their free time, children help in the garden to learn traditional techniques. }\end{array}$ \\
\hline Equity & Men and women take part in the production process. \\
\hline Human Safety and Health & $\begin{array}{l}\text { The members of the community do not have social and medical insurance, but } \\
\text { the companies are provided with a first aid kit to deal with minor injuries. }\end{array}$ \\
\hline Cultural Diversity & $\begin{array}{l}\text { Farms exchange and grow native seeds by encouraging the cultivation of locally } \\
\text { adapted varieties of the local diet. }\end{array}$ \\
\hline
\end{tabular}




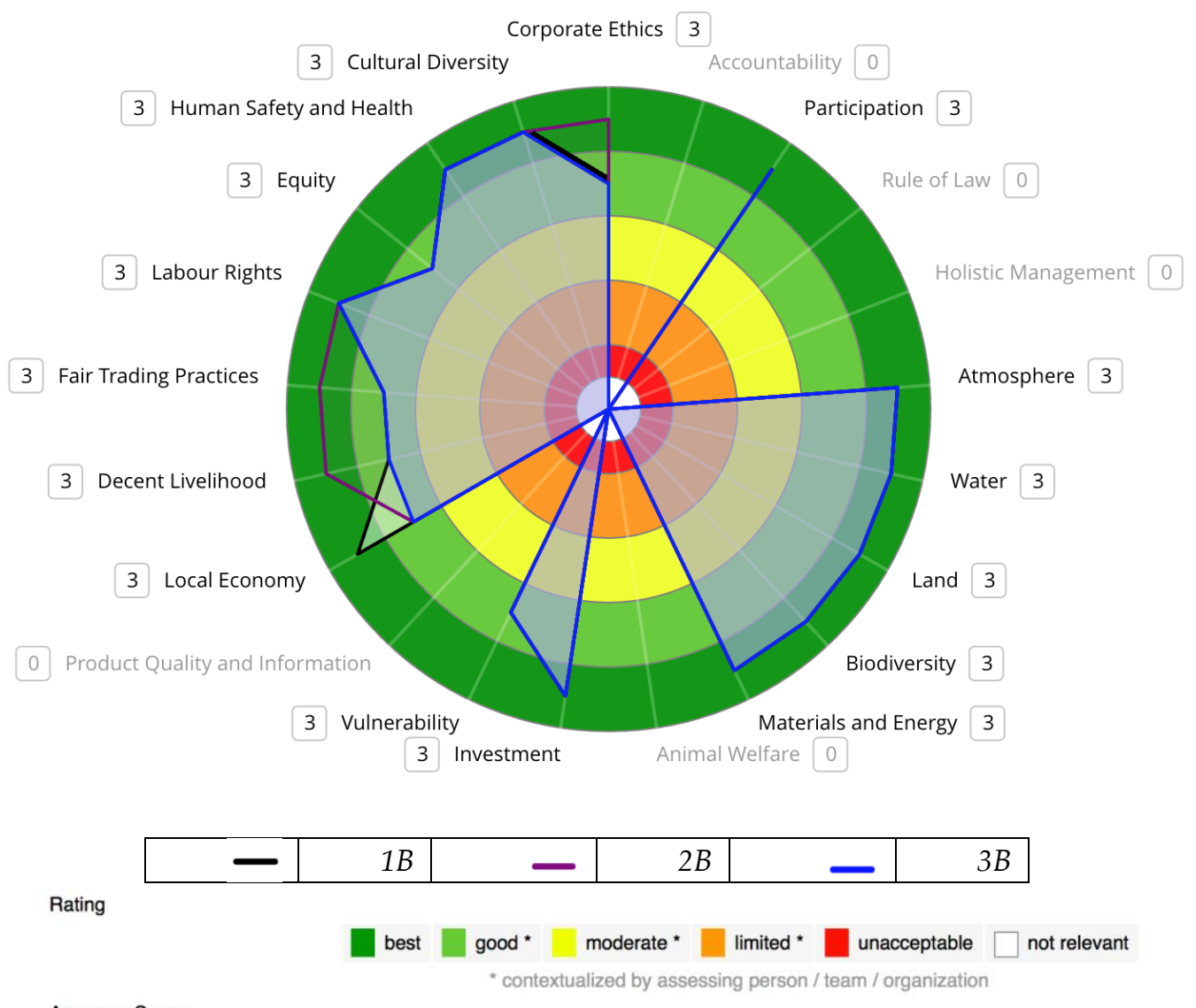

Accuracy Score

1 Low quality data 2 Moderate quality data 3 High quality data

Figure 3. Agroecological peasant family farming SAFA radar chart.

There are differences—-which are in this case slight—-between the levels of sustainability achieved by the three farms in the following themes: "Corporate Ethics and Local Economy" were both very good for $2 \mathrm{~B}$, since the workers are from the area, and the cultivated products are destined for an extremely close trade; Decent Livelihood was also very good for 3B, as the workers' rights are respected through proper shifts.

\subsubsection{Conventional Peasant Family Farming}

The results obtained by the three conventional peasant family farms are very similar to each other and are between good and very good levels of sustainability (Figure 4 and Table 6). The themes in which the three farms have achieved the same levels of sustainability are as follows. "Atmosphere" and "Land" were good, due to efficient practices and preservation of the atmosphere and soil. "Investment" and "Vulnerability" had good levels of sustainability, since there is a collaboration with the agronomists of the ministry in order to acquire useful techniques for the success of the production, thus reducing the vulnerability of the company. Regarding the issue of the "Local Economy", the levels of sustainability are good, since the production is aimed at self-consumption and local sales. There were good levels for the themes of "Decent Livelihood" and "Fair Trading Practices", since the work is not too heavy, and the themes of fair trade are respected. There were very good levels for "Labor Rights", since there are no real working relationships putting into play family dynamics based on solidarity and reciprocity. There were also good levels of "Equity", since women play an important role by participating in agricultural work. 
Table 6. Conventional peasant family farming internet information.

\begin{tabular}{|c|c|}
\hline \multicolumn{2}{|r|}{ Conventional Peasant Family Farming } \\
\hline \multicolumn{2}{|r|}{ Good Governance } \\
\hline Corporate Ethics & Companies do not have a mission clearly focused on sustainable development. \\
\hline Participation & $\begin{array}{l}\text { The members of the farms are part of committees, and all the workers take part } \\
\text { in the decision-making process. In } 1 C \text {, the owner was the promoter of a } \\
\text { committee of women, and now she is the treasurer; in } 3 C \text {, the head of the family } \\
\text { is the chairman of a committee. }\end{array}$ \\
\hline \multicolumn{2}{|r|}{ Environmental Integrity } \\
\hline Atmosphere & No machinery is used; air quality is not affected. \\
\hline Water & $\begin{array}{l}\text { In } 1 C \text {, the garden is irrigated manually with a hose or by sprinkler twice a day, } \\
\text { while the field depends on the precipitation. Where the garden is sloping, } \\
\text { terraces with plastic bottles have been built in order to reduce water loss. } \\
2 \mathrm{C} \text { uses drip irrigation. In } 3 \mathrm{C} \text {, crops depend on rain, and for this reason, } \\
\text { drought-resistant varieties are cultivated. In all cases, shading nets are used to } \\
\text { protect the vegetables from the sun. }\end{array}$ \\
\hline Land & $\begin{array}{l}\text { Crop rotation and associated cultivation is used. To fertilize the land poultry, } \\
\text { ash and compost from food residues and chemicals are used. In order to keep } \\
\text { pests under control, synthetic pesticides, manure, and alcohol-based herbal } \\
\text { solutions are used. Plastic mulch is used in order to prevent the growth of } \\
\text { weeds, keep the soil moisture, and protect the soil from erosion. }\end{array}$ \\
\hline Biodiversity & $\begin{array}{l}\text { Generally, the production is diversified between the products for sale and those } \\
\text { for self-consumption. Different varieties of vegetables and fruits are cultivated. } \\
\text { Hens, cows, and pigs are raised for the production of milk, cheese, eggs, and } \\
\text { meat for self-consumption and for sale in the local market. }\end{array}$ \\
\hline Materials and Energy & $\begin{array}{l}\text { The work in the garden is mainly manual. } \\
\text { In } 2 \mathrm{C} \text {, a portable motor plow is used, and in } 1 \mathrm{C} \text { and } 3 \mathrm{C} \text {, vegetable residues are } \\
\text { used for feeding animals or to make compost. }\end{array}$ \\
\hline \multicolumn{2}{|r|}{ Economic Resilience } \\
\hline Investment & $\begin{array}{l}\text { 1C would like to make an investment to improve the irrigation system but } \\
\text { cannot access an agricultural credit because the holder has exceeded the } 60 \text {-year } \\
\text { threshold, a term beyond which the loan is not granted. } \\
2 \mathrm{C} \text { has invested about } \$ 1500 \text { in shading networks, a motor, and a tank for the } \\
\text { drip irrigation system. }\end{array}$ \\
\hline Vulnerability & $\begin{array}{l}\text { Collaboration with the agronomists of the Ministry of Agriculture in order to } \\
\text { acquire useful techniques for the success of the production. } \\
\text { In } 2 \mathrm{C} \text {, some tools were supplied to the company thanks to a project by the } \\
\text { Ministry of Agriculture }\end{array}$ \\
\hline Local Economy & $\begin{array}{l}\text { Production is aimed at self-consumption and local sales. } \\
\text { Regional workforce. }\end{array}$ \\
\hline \multicolumn{2}{|r|}{ Social Well-Being } \\
\hline Decent Livelihood & The work is not heavy. \\
\hline Fair Trading Practices & $\begin{array}{l}\text { There are no real and proper working relationships, putting into play family } \\
\text { dynamics based on solidarity and reciprocity. }\end{array}$ \\
\hline Labor Rights & $\begin{array}{l}\text { There are no real and proper working relationships, putting into play family } \\
\text { dynamics based on solidarity and reciprocity. }\end{array}$ \\
\hline Equity & $\begin{array}{l}\text { Women play an important role by participating in agricultural work or } \\
\text { managing the company's income. }\end{array}$ \\
\hline Human Safety and Health & $\begin{array}{l}\text { Workers do not have social and medical insurance. Hospitals can be easily } \\
\text { reached by public transport, and there are first aid kits available on the farms. }\end{array}$ \\
\hline Cultural Diversity & Foods grown are part of the local diet following ancestral traditions. \\
\hline
\end{tabular}




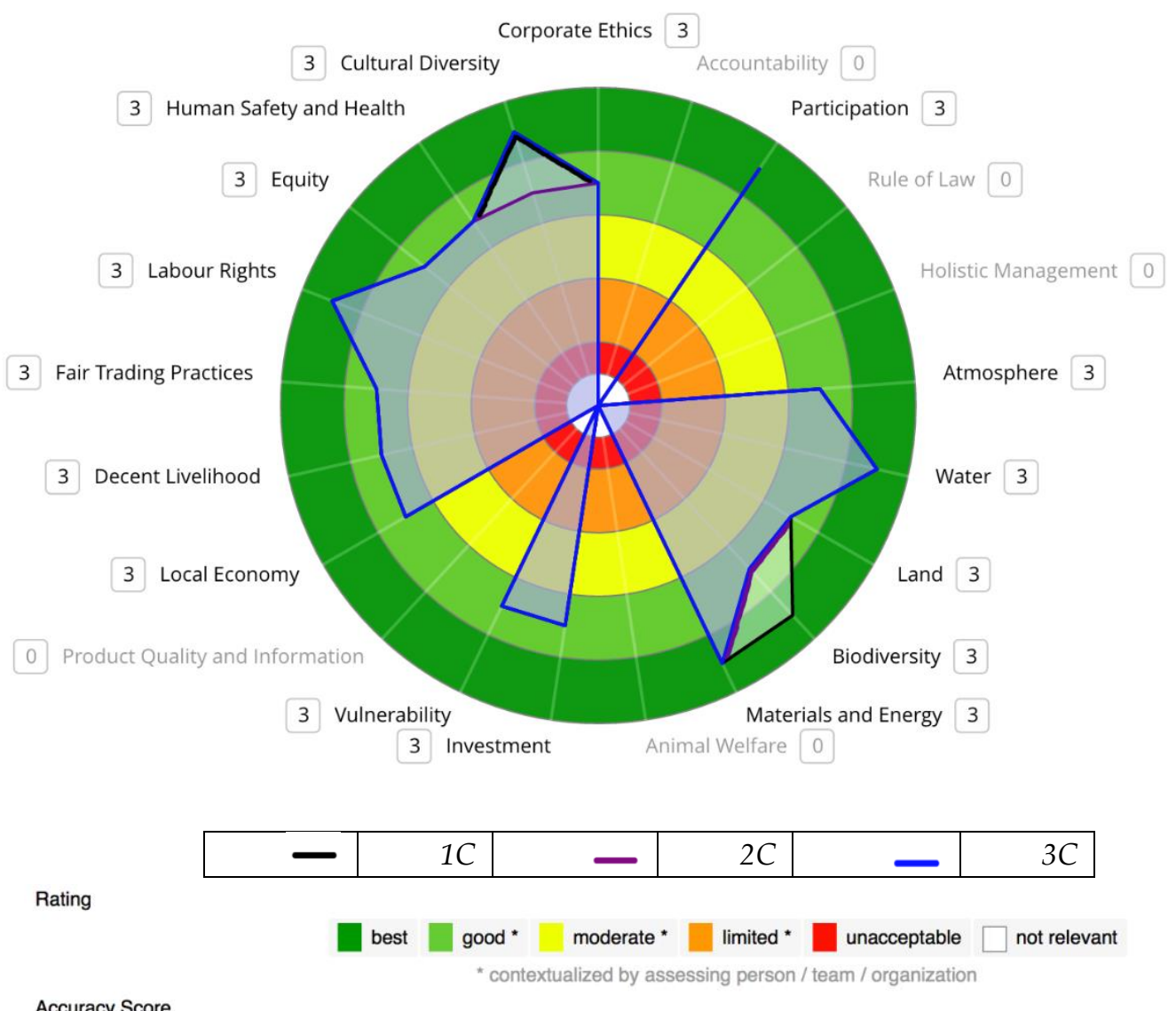

Accuracy Score

$$
1 \text { Low quality data } 2 \text { Moderate quality data } 3 \text { High quality data }
$$

Figure 4. Conventional peasant family farming SAFA radar chart.

There are differences, in this case slight, between the levels of sustainability achieved by the three farms in the following topics: "Biodiversity" was very good for $1 \mathrm{C}$, since a great variety of products is grown; "Cultural Diversity" was very good for $1 \mathrm{C}$ and $3 \mathrm{C}$, as companies cultivate food that are part of the local diet following the ancestral traditions.

\subsubsection{Neo-Rural Farming}

The results obtained by the neo-rural companies, that are part of the "Red Agroecologica" of Asunción, are very similar to each other, and are between good and very good levels of sustainability (Figure 5 and Table 7). The themes in which the three farms have achieved the same levels of sustainability are as follows. "Participation" had a very good score, as all the workers take part in the company's decision-making process. "Land" had very good sustainability levels, as the company focuses on natural fertilization and soil conservation practices. "Vulnerability" was good, since companies do not depend on external sources. The companies achieved a good level of sustainability in the "Local Economy", since the products are sold in small local markets in direct contact with consumers. "Decent Livelihood" had a good level of sustainability, as workers have time for the family and home care. "Fair Trading Practices" and "Equity" had good levels, as companies are based on fair trade. "Human Safety and Health" and "Cultural Diversity" had very good levels, because the companies provide medical insurance to their workers, and because the seeds are exchanged with other small producers, keeping local varieties alive and stimulating food sovereignty, allowing a healthy and adequate diet. 
Table 7. Neo-rural farming interview information.

\begin{tabular}{|c|c|}
\hline \multicolumn{2}{|r|}{ Neo-Rural Farming } \\
\hline \multicolumn{2}{|r|}{ Good Governance } \\
\hline Corporate Ethics & $\begin{array}{l}\text { Farms' aims include leading a healthy life and cultivating products while } \\
\text { respecting the environment. }\end{array}$ \\
\hline Participation & $\begin{array}{l}\text { All workers take part in the decision-making process of the company, are mindful } \\
\text { of committees, and participate in meetings. }\end{array}$ \\
\hline \multicolumn{2}{|r|}{ Environmental Integrity } \\
\hline Atmosphere & No machinery is used; air quality is not affected. \\
\hline Water & $\begin{array}{l}\text { 1D has two pools that are filled with rainwater, which is taken to irrigate the garden. } \\
\text { Shading nets are used to protect crops from the sun. } \\
\text { 2D has a well, a reservoir, and a large pool where rainwater is collected. }\end{array}$ \\
\hline Land & $\begin{array}{l}\text { These are agro-ecological farms for which no chemical fertilizer or insecticide is } \\
\text { used. To increase the fertility of the soil, natural remedies are used such as legume } \\
\text { green manure, compost with garden residues, crop rotation, and associated } \\
\text { cultivation. Plastic mulch is used in order to prevent the growth of weeds, maintain } \\
\text { the moisture in the soil, and protect the soil from erosion. }\end{array}$ \\
\hline Biodiversity & $\begin{array}{l}\text { A wide variety of vegetables and fruits are cultivated. In } 1 \mathrm{D} \text { and } 2 \mathrm{D} \text {, some pigs and } \\
\text { hens are bred for the production of meat and eggs. 1D is also dedicated to the } \\
\text { cultivation of aromatic and ornamental plants. }\end{array}$ \\
\hline Materials and Energy & $\begin{array}{l}\text { Food waste is avoided, and materials recycling is encouraged. } \\
\text { In 1D, the surplus food is sold at lower prices or donated, supplied as food to the } \\
\text { animals, or used as compost. Agricultural work is mainly manual. } \\
\text { 3D has a machine for shredding leaves in order to obtain a compost and a small } \\
\text { portable plow. For market sales, reusable wooden, plastic, and polystyrene boxes } \\
\text { are used. }\end{array}$ \\
\hline \multicolumn{2}{|r|}{ Economic Resilience } \\
\hline Investment & $\begin{array}{l}\text { 2D plans to buy more land, install an irrigation system, give the estate a focus on } \\
\text { eco-sustainable tourism, and find new marketing channels. }\end{array}$ \\
\hline Vulnerability & $\begin{array}{l}\text { 1D does not have access to funding from the State, but in case of need relies on } \\
\text { informal financial sources. The family has other sources of income: the garden is } \\
\text { seen mainly as a source of self-consumption and small trade to support the costs of } \\
\text { land management. The agricultural work in 2D does not allow covering the costs of } \\
\text { the production; however, the company supports this method for the intrinsic value } \\
\text { of the agroecology. 3D has been active for two years, and only recently began to } \\
\text { make profits, supporting itself thanks to its own financial resources. }\end{array}$ \\
\hline Local Economy & $\begin{array}{l}\text { Production for self-consumption and trade in local markets and through a home } \\
\text { delivery service. } \\
\text { 2D is based on the voluntary work of young people, especially Europeans, who } \\
\text { spend a period in the structure-on average between two and three weeks-to } \\
\text { dedicate themselves to agricultural work in exchange for food and lodging. Upon } \\
\text { arrival at the facility, the young volunteers receive training and are supported } \\
\text { during work. Farms generally sell their products at a slightly lower price than in } \\
\text { the supermarket in order to educate the consumer to recognize the quality and taste } \\
\text { of organic products. }\end{array}$ \\
\hline \multicolumn{2}{|r|}{ Social Well-Being } \\
\hline Decent Livelihood & Workers have time for rest, family, and culture, earning at least the minimum wage. \\
\hline Fair Trading Practices & $\begin{array}{l}\text { Companies are based on fair trade. In 1D, the staff is composed of a married couple } \\
\text { and two permanent workers, and when needed, they are helped by friends } \\
\text { and relatives. } \\
2 \mathrm{D} \text { is run by a young couple from Asunción where two employees and various } \\
\text { foreign volunteers work. } \\
\text { In 3D, a family hired by the owners takes care of the garden. }\end{array}$ \\
\hline
\end{tabular}


Table 7. Cont.

\begin{tabular}{cl}
\hline & \multicolumn{1}{c}{ Neo-Rural Farming } \\
\hline Labour Rights & $\begin{array}{l}\text { In 2D, the staff works from 06:00 to 11:00 in order to take advantage of the coolest } \\
\text { hours of the day and be able to dedicate the rest of the time to other activities. The } \\
\text { owners of the company have a university education in biology and agricultural } \\
\text { administration. }\end{array}$ \\
\hline $\begin{array}{c}\text { Equity } \\
\text { Health }\end{array}$ & Men and women take part in the production process equally. \\
\hline Cultural Diversity & $\begin{array}{l}\text { The seeds are exchanged with other small producers, keeping the local varieties } \\
\text { alive, stimulating food sovereignty, and allowing a healthy diet. }\end{array}$ \\
\hline
\end{tabular}

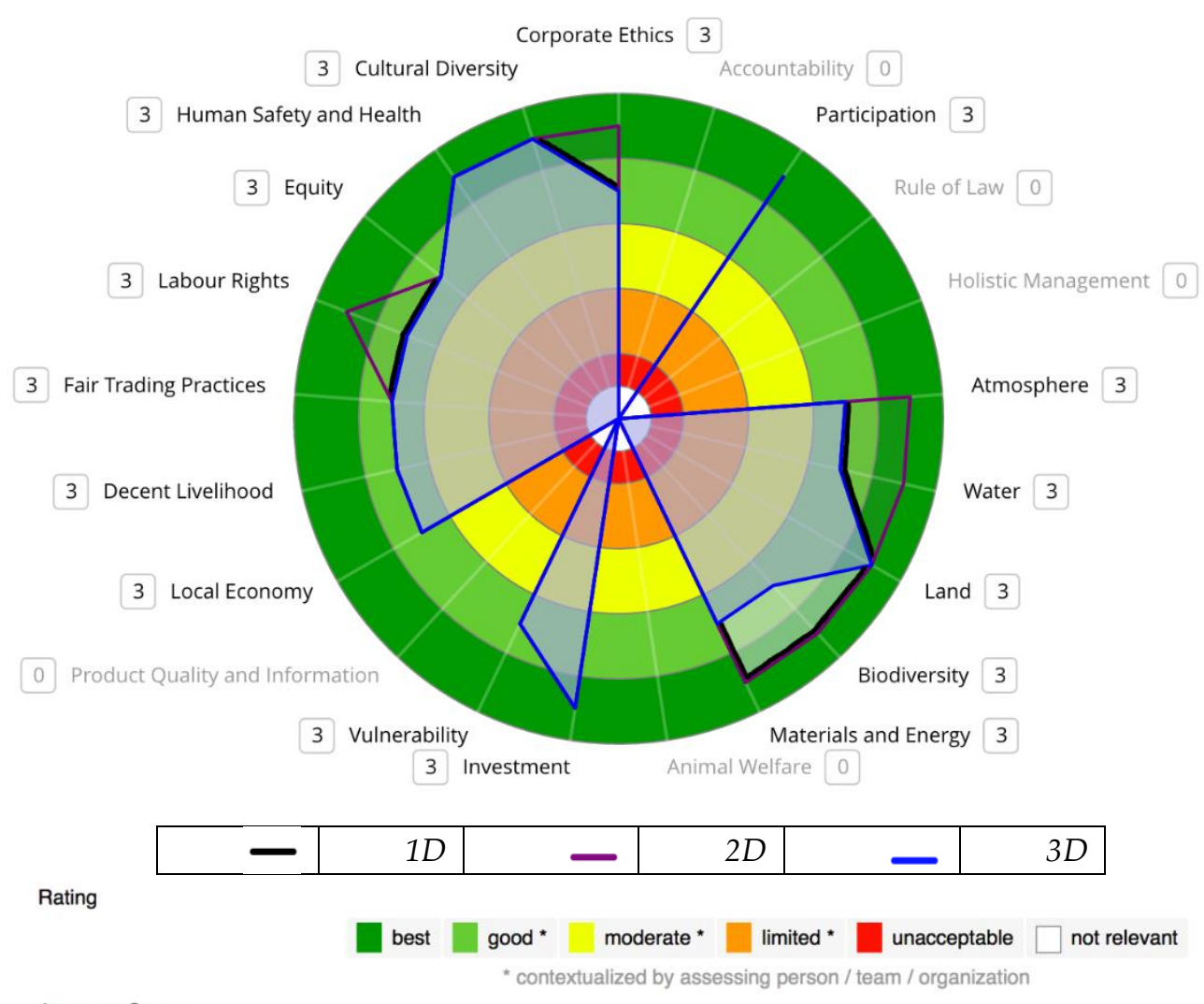

Accuracy Score

$$
1 \text { Low quality data } 2 \text { Moderate quality data } 3 \text { High quality data }
$$

Figure 5. Neo-rural farming SAFA radar chart.

There are differences, which are in this case slight, between the levels of sustainability achieved by the three farms in the following themes. Regarding "Corporate Ethics", 2D was very good, since in general, the business ethics are focused on sustainable development. In "Water", 2D achieved very good levels of sustainability because the water from the river is used sparingly. "Biodiversity" and "Materials and Energy" had good scores for 3D, as a great variety of products is cultivated, food waste is avoided, and the recycling of materials is encouraged. "Labor Rights" had good levels of sustainability for 1D and 3D and very good levels for 2D, as the company respects the rights of its workers and provides them with a fair salary. 


\subsubsection{Indigenous Agriculture}

As regards indigenous agriculture, the indigenous communities of "Pai Tavytera" ethnicity located in the district of Captain Bado in the Department of Amambay have been analyzed (Figure 6 and Table 8).

The results obtained by the three communities are equal to each other, and are between good and very good levels of sustainability. The communities have achieved the following results: good sustainability practices in "Corporate Ethics", as the communities aim to safeguard and respect the environment; very good levels in "Participation", as decisions are made in groups; good levels for "Atmosphere" and very good for "Water, Land, Materials, and Energy" and "Biodiversity", thanks to the high genetic variability of cultivated products; good levels of sustainability in the themes of "Investment" and "Vulnerability" due to the great variety of cultivated vegetables that make it possible to obtain a diversified production throughout the year. The three communities have also obtained very good scores in the themes of "Local Economy" and "Cultural Diversity", as agriculture is based on ancestral knowledge, cultivating native species that are part of the local diet. There are good levels in the themes of "Decent Livelihood", "Fair Trading Practices", "Labor Rights", "Human Safety, and "Health" and "Equity" since both men and women take part in the production process, carrying out various tasks.

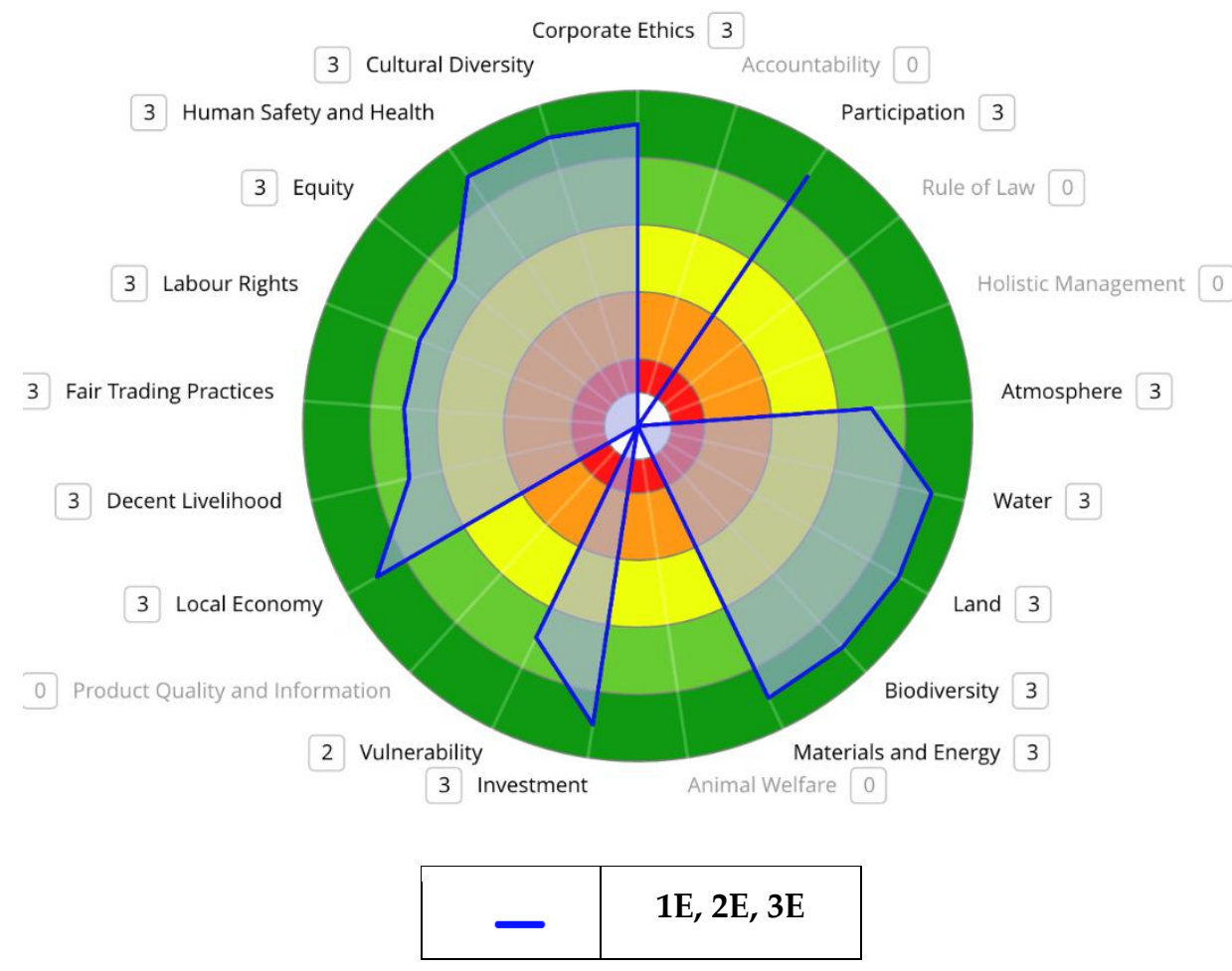

Rating

Accuracy Score

best $\square$ good * $\square$ moderate * $\square$ limited * $\square$ unacceptable $\square$ not relevant

* contextualized by assessing person / team / organization

1 Low quality data 2 Moderate quality data 3 High quality data

Figure 6. Indigenous agriculture SAFA radar chart. 
Table 8. Indigenous agriculture interred information.

\begin{tabular}{|c|c|}
\hline \multicolumn{2}{|r|}{ Indigenous Agriculture } \\
\hline \multicolumn{2}{|r|}{ Good Governance } \\
\hline Corporate Ethics & $\begin{array}{l}\text { Communities aim at safeguarding and respecting the environment; nature is } \\
\text { considered sacred by the natives, and is seen not only as a means of production } \\
\text { but as a space for social and religious life: the earth, the woods, and the } \\
\text { waterways belong to the whole community, so everyone must work to their } \\
\text { protection and conservation. }\end{array}$ \\
\hline Participation & $\begin{array}{l}\text { The extended family is the unity of the indigenous society within which } \\
\text { decisions are made. The elderly are the heads of the family group, and men and } \\
\text { women share the decision-making process and responsibilities. }\end{array}$ \\
\hline \multicolumn{2}{|r|}{ Environmental Integrity } \\
\hline Atmosphere & No machinery is used; air quality is not affected. \\
\hline Water & $\begin{array}{l}\text { Crops are not irrigated, and the soil is covered with leaves and garden residues } \\
\text { in order to maintain humidity. }\end{array}$ \\
\hline Land & $\begin{array}{l}\text { Maintaining the quality of the soil, the communities resort to leguminous green } \\
\text { manure, crop rotation, and associated cultivation, periodically leaving the earth } \\
\text { to rest. }\end{array}$ \\
\hline Biodiversity & High genetic variability of cultivated products. \\
\hline Materials and Energy & Lacking running water and electricity, wood serves as the sole source of energy. \\
\hline \multicolumn{2}{|r|}{ Economic Resilience } \\
\hline Investment & $\begin{array}{l}\text { Families are investing in buying mobile phones and motorcycles to improve } \\
\text { communication and transports. }\end{array}$ \\
\hline Vulnerability & $\begin{array}{l}\text { The availability of food from agriculture fluctuates during the year and is } \\
\text { significantly affected by climatic conditions, so the consumption of its products } \\
\text { is low during the winter months, with the exception of cassava, which is the } \\
\text { main basis of the community's indigenous diet along with corn, which can be } \\
\text { kept for long periods. }\end{array}$ \\
\hline Local Economy & $\begin{array}{l}\text { Food for self-consumption, where excess products are exchanged with other } \\
\text { goods or sold in local markets or at the agroecological market in the capital. }\end{array}$ \\
\hline \multicolumn{2}{|r|}{ Social Well-Being } \\
\hline Decent Livelihood & The work is not too heavy, leaving room for the family and leisure time. \\
\hline Fair Trading Practices & $\begin{array}{l}\text { The principle of mutual aid and reciprocity among the members of the } \\
\text { community is called jopói and consists of an exchange of goods and favors, in } \\
\text { which the return is not necessarily immediate. }\end{array}$ \\
\hline Labour Rights & $\begin{array}{l}\text { There are no real "employee-employer" working links, but there are solidarity } \\
\text { ties between family members. }\end{array}$ \\
\hline Equity & $\begin{array}{l}\text { According to the social organization, men are dedicated to hunting and } \\
\text { preparing the land, while women are involved in sowing, harvesting, preparing } \\
\text { food, and economically administering the family. }\end{array}$ \\
\hline Human Safety and Health & $\begin{array}{l}\text { Families do not have medical insurance, are wary of public health, and are } \\
\text { treated according to their ancestral knowledge. }\end{array}$ \\
\hline Cultural Diversity & $\begin{array}{l}\text { Agriculture is based on ancestral knowledge. Use native species that are part of } \\
\text { the local diet. Agricultural work is carried out following a lunar and seasonal } \\
\text { calendar; the production process is linked to a series of religious rites. }\end{array}$ \\
\hline
\end{tabular}

\subsection{Evaluation of the Sustainability Level of Agricultural Systems in a Comparative Way for Each Dimension}

In this paragraph, the sustainability level of each type of agricultural system will be compared for each sustainability dimension (political, environmental, economic, and social) and in a comprehensive manner. 


\subsubsection{Good Governance}

In the Good Governance dimension (Figure 7), it is possible to observe that the peasant family farming, neo-rural, and indigenous agriculture have achieved high levels of sustainability thanks to good business ethics and excellent participation. The representatives of these agricultural typologies declare that in their mission, they commit themselves in favor of the sustainability toward the consumers and the stakeholders (Tables 5-8). For agribusiness, on the other hand, the people involved in the interviews expressed that their mission is mainly productive with the aim of obtaining the greatest return at the lowest cost (Table 4).

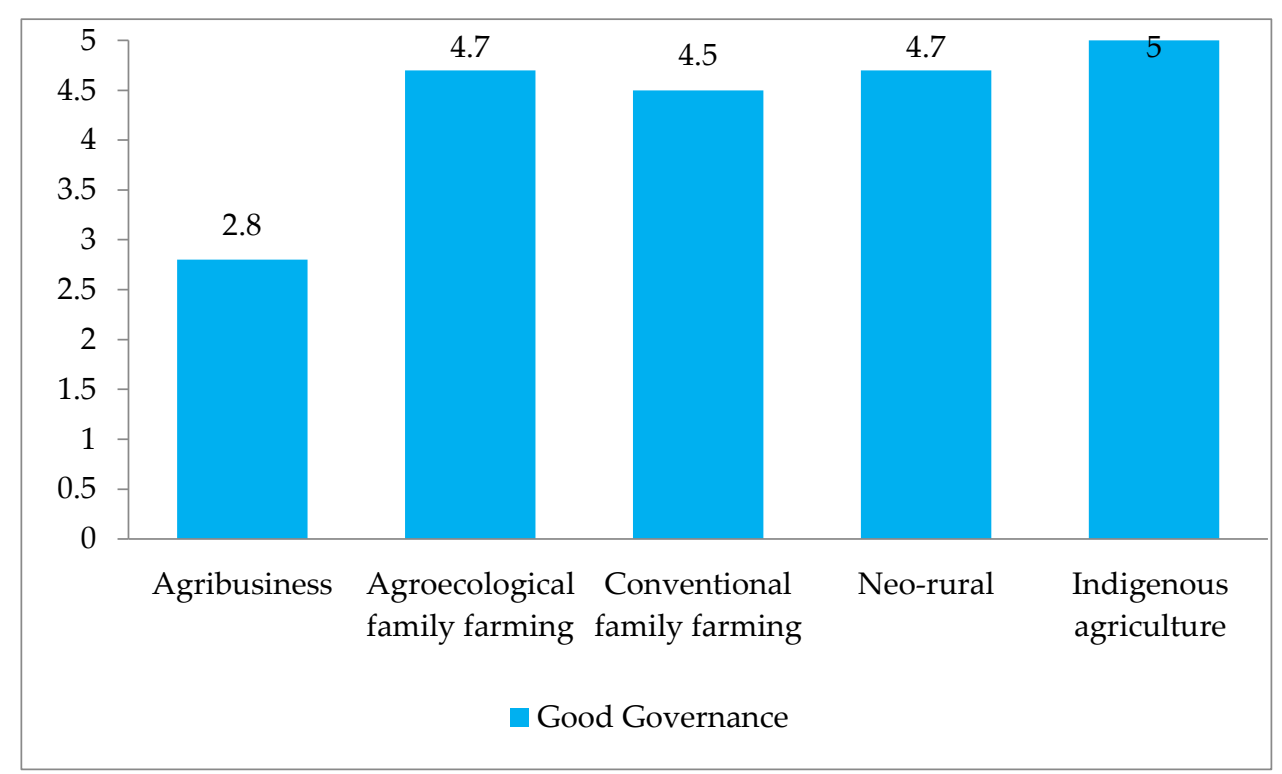

Figure 7. Good Governance sustainability chart. FAO's score values: 4-5 (Best); 3-4 (Good); 2-3 (Moderate); 1-2 (Limited); 0-1 (Unacceptable).

The representatives of peasant family farming, for conventional, agro-ecological, neo-rural, and indigenous agriculture, declare that they examine the possible long-term consequences in the environmental, economic, social, and political spheres of sustainability before making decisions. This is done by following appropriate procedures such as risk assessment. This aspect is less evident in the field of agribusiness, which mainly uses leased land and labor entrusted to third parties. In some cases, the agribusiness companies do not own the plots of land, but instead rent them to various small owners or have agreements whereby the small landowners allocate the entire portion of their harvest to the company. Company workers report that fertilizers and pesticides are used to maximize production and minimize losses, and once the yield is lowered because the land is no longer productive, the company looks for new land to rent. On the contrary, the exponents of peasant and indigenous family agriculture report that they own a small plot of land that is in most cases their only source of livelihood, so they try to make the most of it by preserving its resources. Participation refers to the involvement of stakeholders, and includes the ability to take an active part in the decision-making process, which happens in most cases except for agribusiness. In fact, the big companies involved in the research are not able to fully identify all the people involved in the company's activities. Workers are often paid daily for work done; in this way, from the interviews, it appears that a link with the company is not established and access to fundamental rights is not obtained such as employment insurance, a regular contract, and a fair salary. Employed workers declare that if on the one hand power asymmetries can be reduced through clear, accessible, and fair complaints procedures, these means are not provided, just as trade union struggles are not allowed. In the cases of peasant family farming, which is neo-rural and indigenous, on the other hand, the producers declare that in most cases, they set up committees 
where they meet once or twice a month to discuss production and any problems that need to be solved through consensus.

\subsubsection{Environmental Integrity}

In the environmental dimension (Figure 8), the analyzed farms corresponding to family farming, neo-rural, and indigenous agriculture have achieved high levels of sustainability, as they use efficient irrigation practices and good soil conservation strategies (Table 8). Moreover, in these companies, a high degree of biodiversity appears because they cultivate a great variety of products; unlike in the analyzed companies that are based in agribusiness land is used for monocultures. As stated in the interviews, the agricultural work of the peasant, neo-rural, and indigenous farming systems (Tables 5-8) is mostly manual, reducing the consumption of fossil fuels; degraded lands are restored and native forests are conserved, helping to mitigate their greenhouse gas emissions. In fact, according to the $\mathrm{FAO}$, deforestation and forest degradation contribute to $10-11 \%$ of global greenhouse gas emissions, while reforestation and agro-forestry represent mitigation potential [51]. Instead, for agribusiness, synthetic fertilizers and machinery are used, resorting to deforestation to use large areas of arable land.

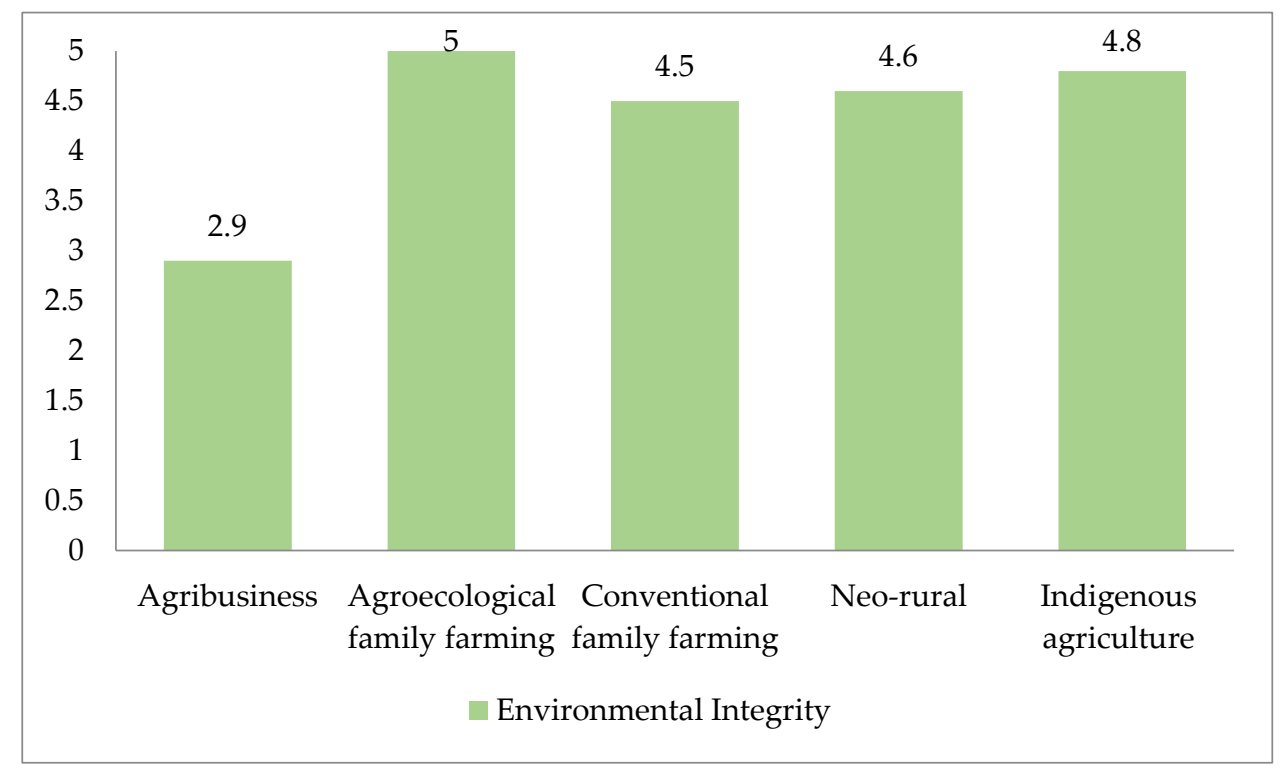

Figure 8. Environmental Integrity sustainability chart. FAO's score values: 4-5 (Best); 3-4 (Good); 2-3 (Moderate); 1-2 (Limited); 0-1 (Unacceptable).

The current global agri-food system, led by a powerful transnational food industry, is responsible for a percentage between a minimum of $44 \%$ and a maximum of $57 \%$ of all man-made greenhouse gas emissions [54]. Chemical fertilizers, heavy machinery, and other petroleum-dependent agricultural technologies contribute significantly. Most of the studies establish that the contribution of agricultural emissions, i.e., the emissions produced in cultivated fields, is between $11-15 \%$ of global emissions [55]. Furthermore, $15-18 \%$ of global greenhouse gas emissions derive from the change in land use and from the deforestation caused by agriculture [54].

The producers of peasant family farming, neo-rural, and indigenous agriculture adopt practices that aim to save water; for example, some crops depend totally on rainfall, while others are irrigated sparingly. For this reason, small producers claim to prefer drought-resistant plant species. They also use soil management practices that aim to improve the physical, chemical, and biological properties of soils, such as the controlled application of organic fertilizers to improve nutritional deficiencies, the use of compost to improve soil organic matter content, associated cultivation, and crop rotation, as well as conservation and restoration of degraded lands (Tables 5-8). The analyzed farms belonging to agribusiness use larger quantities of pesticides and synthetic fertilizers on their monocultures (Table 4). 
Paraguay officially imported 152,067 tons of chemicals (with an average of 7.4 kilos of agrochemicals per inhabitant) for a value of $\$ 419,438,666$ dollars in 2017. It represents $6.2 \%$ of the world total commercial value, which is an extraordinary amount if we consider that it refers to a small country with a cultivated land of 5,839,000 hectares. Paraguay also imported 1,519,154 tons of fertilizers, which were valued at $402,709,447$ dollars, in the same years. According to the statistical data, Paraguay increased the import of agrochemicals between 2016-2017 to approximately 7000 tons, and the rate of growth continues to increase [56].

From 2009 to 2016, the import of agricultural pesticides has increased by five times and this trend has coincided with the massive liberalization of genetically modified seeds [57]. Often within the properties belonging to exponents of peasant family farming, neo-rural agriculture, and indigenous agriculture, there is a large part of native forest that is not used for agricultural purposes, creating a high structural diversity of the landscape that positively influences ecosystem services. This has a direct impact on the environment in that it minimizes soil erosion and increases fertility, as well as provides other environmental services such as natural pest control. In the cases of agribusiness, the presence of native trees or forests that are capable of preventing soil erosion is very low.

The product of the farms classified as peasant family farming, neo-rural agriculture, and indigenous agriculture is destined to self-consumption and local sale. In general, rare, endemic, and endangered species belonging to the local cultural heritage are cultivated. The large-scale producers of monocultures, on the other hand, use partly treated and genetically modified seeds. The use of materials, such as plastic and cardboard for packaging, is in most cases limited, preferring the use of recycled and renewable materials. The use of energy is also limited, especially in the cases of peasant family farming, neo-rural farms, and indigenous farms where work is manual, as opposed to agribusiness cases, where work is completely automated. In most cases, the residues produced by cultivation are left on the ground as a covering in order to maintain its humidity or used for the production of a compost to fertilize the soil, or to feed the farm animals.

\subsubsection{Economic Resilience}

As regards the economic dimension (Figure 9), it is possible to note that all the analyzed farms have achieved at least a good level of sustainability. In most cases, the workforce used by the farms comes from the local community, thus encouraging the economy of the area. Almost all the producers, especially those belonging to agribusiness, agro-ecological peasant family farming, and neo-rural agriculture, have a business plan that describes the current state of the company, its aims, and objectives. This is because these categories of agricultural systems claim to be more focused on marketing. Producers belonging to conventional peasant family farming often do not have a clear business plan, even if they are part of local committees. Usually, the main purpose of production is subsistence, reserving only a part for sale.

Net profit is an index of economic activity that helps effectively measure the company's profitability and financial sustainability over time. In this case, the agribusiness companies show greater profitability, while those belonging to neo-rural agriculture and peasant family farming report having to rely on additional sources of income in order to sustain themselves financially over time.

Internal risks are those in which the company can have greater control, such as for example accidents in the workplace. The external risks are those over which the company has no control, such as heavy rain or drought. There are a number of strategies that can be adopted by farms to manage risks, such as the development of a risk adaptation and mitigation plan. The agribusiness monocultures are more vulnerable, and the risk of losing the harvest is greater than the crops of small producers that have a high biodiversity. 


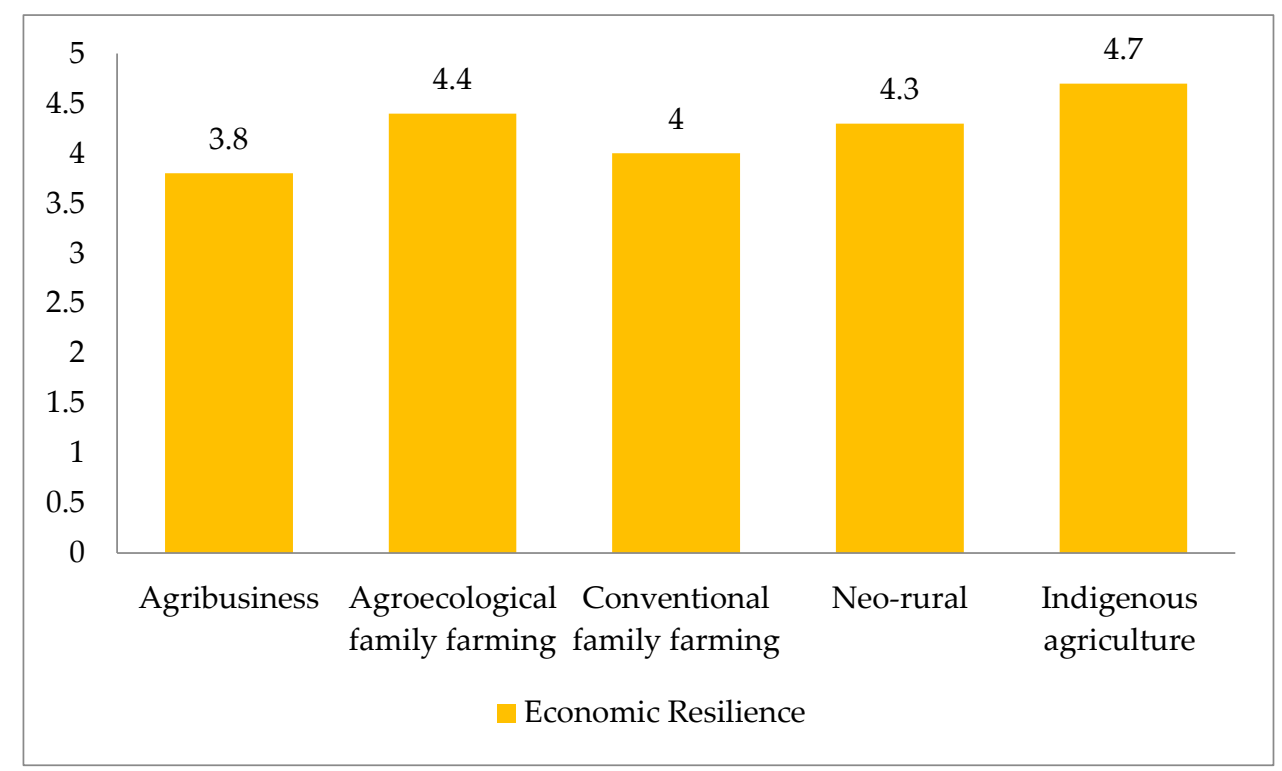

Figure 9. Economic Resilience sustainability chart. FAO's score values: 4-5 (Best); 3-4 (Good); 2-3 (Moderate); 1-2 (Limited); 0-1 (Unacceptable).

The greater efficiency depends on the manual labor optimizing the land. While large-scale monocultures maximize the yield of a single crop, small-scale farming cultivates many varieties of products using land cover and combining agriculture with forestry, enriching the soil and maximizing plant density per hectare, and obtaining benefits from the interaction between plants, creating stability in the ecosystem and decreasing its vulnerability [45]. Concerning this, some studies report that smaller farms can be more productive in terms of yield per area than bigger farms due to the inverse relationship (IR) between size and productivity [58].

The people interviewed attach great importance to the possibility of accessing safety nets, especially in times of crisis, when the farm faces a lack of cash flow and is unable to meet its short-term financial obligations such as the payment of salaries and the purchase of materials. Among these, the interviewees identify formal and informal networks: formal safety nets are for example banks, microcredit institutes, or public social programs; informal security networks, on the other hand, consist of family members, friends, community groups, and non-governmental institutions. In general, the farms analyzed do not refer to formal security networks due to the scarcity of aid programs and limited trust in institutions.

\subsubsection{Social Well-Being}

As far as the social welfare dimension is concerned (Figure 10), it is observed that all the analyzed farms have reached at least good levels of sustainability. The exponents of peasant family farming, neo-rural farms, and indigenous agriculture declare that they engage in sustainable practices to support themselves and their families, have free time to dedicate to family and leisure, guarantee food sovereignty, and respect ancestral knowledge through its own production (Tables 5-8). Regarding the analyzed cases belonging to agribusiness, employees declare that the work shifts are long and heavy, the workers are not paid according to what is foreseen and established by law, and in some cases, the company does not provide the devices necessary to work in safety (Table 4). In the analyzed cases of agribusiness, often the work is entrusted to third parties; in this way, the workers do not have a direct relationship with the farm, but rather with companies that manage the work. Furthermore, many workers are not hired regularly; instead, they are paid per day per kilo of harvested product. These workers are generally involved in the preparation of the land and in the harvest; they do not have social and medical insurance, and must independently obtain the tools to carry out the work. According to data from the General Statistical and Census Directorate, $82 \%$ of the rural population 
in 2014 had no medical coverage against 63\% of the urban population [59]. However, there are also workers who access regular contracts as well as social and medical insurance. In the cases, instead of peasant family farming, neo-rural agriculture, and indigenous agriculture, there is often no real relationship between the employer and employees because the workers are the same members of the family, for which there are no contracts, hours of work, or insurance. There are no episodes of forced and child labor. In some cases, especially with regard to peasant family farming and indigenous agriculture, children help in the garden or spend some of their time with the family in the field, without taking away time and commitment to education and recreation. In the cases of peasant family farming, neo-rural agriculture, and indigenous agriculture, the producers declare that they are part of committees where people meet and discuss work, production, and sales. Usually, the production is destined for its own consumption or for the local trade in which it is sold directly to the consumer. In this way, the price of the products is more convenient for both producers and consumers. Some workers in the agribusiness sector denounce that the company does not allow the association and that the trade union subsequently struggles, and those who try to claim their rights are penalized also with the dismissal. In some cases, agribusiness companies, following their own social policies, hire women and staff with disabilities. Especially in the context of peasant family farming, neo-rural agriculture, and indigenous agriculture, women play an important role in production by dedicating themselves to the care of the family garden and farmyard animals, the sale of products to the market, and the economic administration of the family. Farms rarely provide health coverage to their workers, and the national health system does not adequate cover the needs of citizens. The producers of peasant family farming, neo-rural agriculture, and indigenous agriculture claim to respect and adopt ancestral knowledge. Agribusiness producers, on the other hand, use modern and technological knowledge. Small producers express their interest in guaranteeing food sovereignty (food sovereignty favors the economic, political, and cultural sovereignty of peoples, promoting peasant and indigenous agriculture linked to the territory and oriented toward meeting the needs of local and national markets. It also recognizes the multi-ethnicity of nations and improves the identities of indigenous peoples, which should be recognized for the autonomous control of their territories, natural resources, production systems, and management of rural areas, seeds, knowledge, and organizational forms [23]) through using native seeds that are part of the local diet and are sold in an extremely close market. Women also take part in agricultural work, playing a fundamental role. Agribusiness companies, on the other hand, produce mechanized large-scale crops that are not part of the local diet and are intended for export.

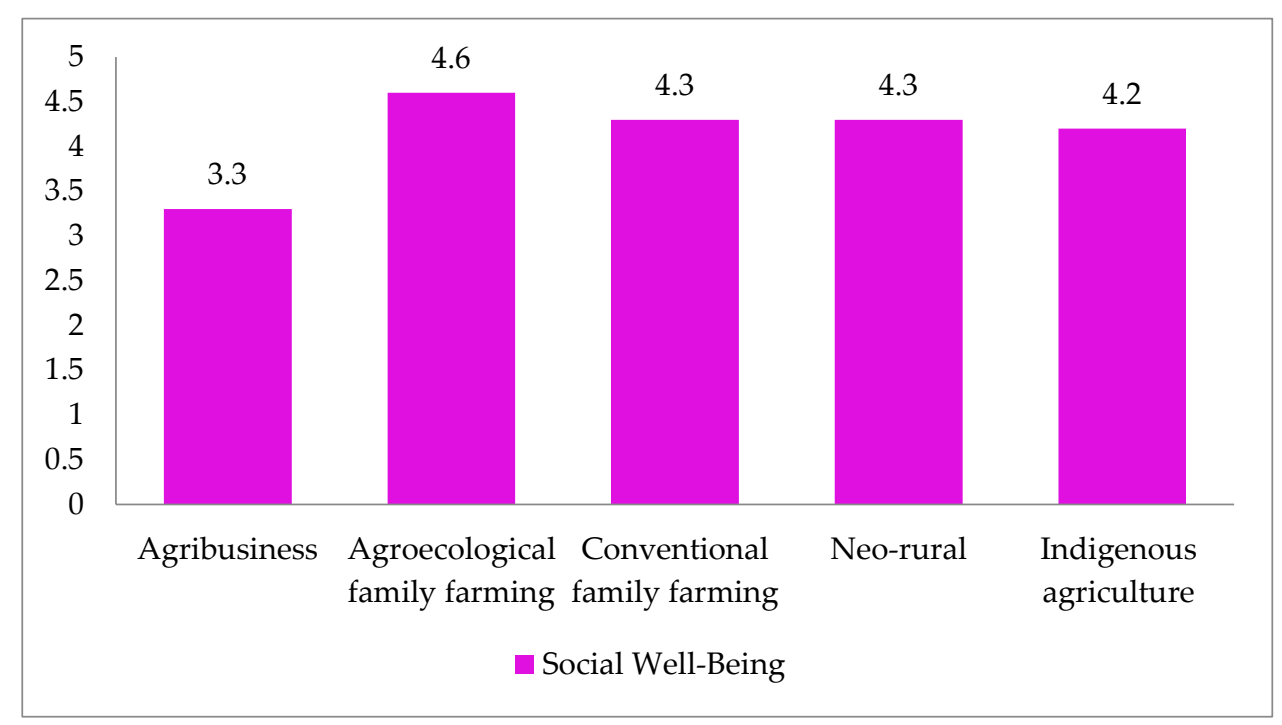

Figure 10. Social well-being sustainability chart. FAO's score values: $4-5$ (Best); 3-4 (Good); 2-3 (Moderate); 1-2 (Limited); 0-1 (Unacceptable). 


\subsection{General Discussion}

Looking at an SAFA chart, it is possible to deduce that sustainability issues are interrelated and each is the cause and consequence of all the others. The results suggest that production systems with high levels of biodiversity that use locally adapted seeds and incorporate soil and water protection practices have a positive impact on farm profitability by reducing its vulnerability to external risks, contributing to and thus preserving the peasant culture and strengthening the security and food sovereignty of the region and the country. The developed analysis pointed out the need for information about the different farm types in Paraguay for improving the current level of policy sustain that is addressed to positive externalities provided by farm activity, and for building new and innovative policy mechanisms for enhancing rural identity and increasing farming sustainability. Furthermore, no previous experience of sustainability assessment of farms in Paraguay was highlighted through the SAFA methodology, so it would be advisable for the state to implement a strategy for assessing the sustainability of farms belonging to different types of agriculture in order to create an updated and complete database. The results of the sustainability assessment can be a motivation for improvements within each individual farm, but also an important tool for providing recommendations to the local government on sustainability issues that should be implemented in the future. It is important that the government focus on identifying alternative approaches to incentivize farmers to create sustainable technological and social progress differentiated by type of farm. The shortcomings in the various themes depend on multiple aspects. Not all farms have sustainable development as their objective, so in some cases, it is necessary to work at the farm level in order to increase the level of awareness and individual commitment toward sustainability issues. At the same time, the criticalities found also concern the regulations and laws of the country. Although public policies aim at sustainable development, a specific regulatory setting for promoting sustainability in agriculture with an agro-ecology perspective is still missing [60]. Agricultural policies are developed with productivist objectives, so that the production of public goods by local/indigenous farms are not sufficiently recognized with the risk of worsening the food sovereignty (i.e., food security) at the national level, as well as significantly reducing the agricultural diversity and the cultural heritage, and losing the rural social texture. Indeed, as Riquelme claimed, most programs and projects are not assimilated or accepted because they are built outside the experiences and knowledge of the families that are subject to these programs [58]. In general, Paraguay has various programs and projects, of which some are financed with external and other with national funds. However, their coverage continues to be scarce, since it does not respond to a national development strategy. The assistance focuses on giving priority to those crops that generate an income, but without looking at the completeness of the farm [61]. It is essential to implement legislative frameworks and regulations that ensure a shift toward sustainable agriculture and systems that respect and protect the rights of producers and their access to productive resources such as land, water, and seeds.

Furthermore, in some cases, such as for the themes "Labor Rights" and "Decent Livelihood", there has been a lack of compliance with certain regulations such as the adequate payment of overtime and the creation of obstacles to labor unions. Therefore, it would be desirable to have greater control over compliance with laws and the protection of producer organizations in order to obtain greater rights at the working level. In the case of the theme related to "Human Safety and Health", there is a lack of both corporate and national welfare; according to the interviews conducted, the employees do not get benefits from the farms they work for, and are wary of public health, because it is considered inefficient. Therefore, it is advisable to increase investments and the presence of the state in matters of health. The shortcomings in the "Investment" theme mainly depend on the state, which should increase the availability of agricultural loans for producers, at low interest rates, without intermediaries, and encourage cooperative financing programs. According to the "Cultural Diversity" theme, it is important to strengthen the participation of women, small farmers, and indigenous peoples as active subjects of life and community development, with programs based on their specific needs, re-evaluating them as key subjects for the construction of food sovereignty. In this regard, the agroecological discipline 
has generated debate on the importance of the role of women for the social reproduction of peasant and indigenous family unity, the maintenance of biodiversity, and environmental sustainability [62]. According to Pacheco [63], the role of women in the sustainable management of natural resources and as an active subject in the construction of knowledge requires an enhancement through organizational support and access to the means of production. In the case of "Vulnerability", the graphs do not show low levels of sustainability, as farms adopt their own strategies. However, it would be desirable to promote and implement legislation that ensures sustainable agriculture support.

\section{Conclusions}

Growing human needs, life styles that are incompatible with the process of regeneration of the environment, and the increase in economic activities are exerting ever-greater pressure on the Earth's resources [1]. The present production model is no longer sustainable, and it is necessary to find alternatives [64]. For this reason, sustainability is an issue that is at the center of current political, economic, social, and environmental discussions, and constitutes the cornerstone of the Sustainable Development Goals [2], which provide a shared program of peace and prosperity for people and the planet, for the present and the future. The sustainability assessment can provide useful information in order to implement improvements by individuals and policy makers, anticipating situations of risk and conflict [20].

Paraguay is a country whose economy is mainly based on agriculture and is characterized by a high poverty index [65]. Rural poverty, unequal land distribution, increased concentration of land in the hands of foreigners, and the growing expansion of large estates for the cultivation of export products are the main factors that undermine the sustainability of the country. The sustainability study in Paraguay can be important and be used as a starting point not only to encourage improvements within each individual farm, but also as an important tool to provide recommendations to the local government on sustainability issues that should be improved for the future. For these reasons, in the present study, we analyzed the sustainability of agricultural systems in Paraguay through the use of SAFA indicators, and in a comparative way for identifying critical issues and improvement strategies for enhancing rural sustainability.

As regards the evaluation of the sustainability level within Paraguayan agricultural systems, peasant family farming, as well as agro-ecological, conventional, neo-rural, and indigenous agriculture proved to be substantially similar at the time of the sustainability assessment, exhibiting excellent results in the four dimensions. The levels of sustainability achieved by agribusiness, on the other hand, deviate from those of other agricultural systems, resulting in moderate scores in the dimensions of good governance and environmental integrity, and good scores in the economic and social dimensions. Agribusiness represents the the most widespread model in terms of cultivated area, thanks to its profitability and orientation to the market.

However, the increasing interest toward sustainable issues, also due to the degradation of natural resources, is slowly driving, in some cases, the introduction of new sustainable practices.

A new agricultural policy reform is necessary for improving agricultural production and public goods in the different types of farms, from economic, environmental, and social standpoints. In this respect, we believe that SAFA methodology represents a useful tool to support policy makers in designing and evaluating policies. As demonstrated in this study, SAFA can be applied for comparing different types of farms and identifying the critical issues for preparing effective intervention policies.

Author Contributions: A.S.: investigation, data, curation and writing - original draft; M.J.A.M.: investigation, methodology and supervision; M.G. methodology, supervision, writing - original draft, writing - review \& editing; M.D. methodology, supervision, writing - review \& editing; A.I.O.: methodology, supervision, project administration.

Funding: The APC was funded by STRENGHT2FOOD project funding from the European Union's Horizon 2020 research and innovation programme under grant agreement No 678024 (https://www.strength2food.eu/).

Conflicts of Interest: The authors declare no conflict of interest. 


\section{References}

1. United Nations Environment Programme (UNEP). Perspectivas del Medio Ambiente Mundial 2002: GEO-3: Pasado, Presente y Futuro; Ediciones Mundi-Prensa: Madrid, Spain, 2002; p. 425.

2. Sustainable Development Goals. Available online: https://sustainabledevelopment.un.org/content/docume nts/4538pressowg13.pdf (accessed on 28 April 2019).

3. Merico, L.F.K. Proposta metodológica de avaliação do desenvolvimento econômico na região do Vale do Itajaí (SC) através de indicadores ambientais. Rev. Dyn. 1997, 5, 59-67.

4. Baroni, M. Ambigüidades e deficiências do conceito de desenvolvimento sustentável. Rev. Adm. Empres. 1992, 32, 14-24. Available online: htp://www.scielo.br/pdf/rae/v32n2/a03v32n2.pdf (accessed on 27 April 2019). [CrossRef]

5. Food and Agriculture Organization of the United Nations (FAO). El Future de la Alimentación y la Agricultura. Tendencias y Desafíos. Available online: http://www.fao.org/3/a-i6881s.pdf (accessed on 28 April 2019).

6. Loaiza Cerón, W.; Reyes Trujillo, A.; Carvajal Escobar, Y. Aplicación del Índice de Sostenibilidad del Recurso Hídrico en la Agricultura (ISRHA) para definir estrategias tecnológicas sostenibles en la microcuenca Centella. Ing. Desarro. 2012, 30, 160-181. Available online: http://www.scielo.org.co/pdf/inde/v30n2/v30n2a03.pdf (accessed on 28 April 2019).

7. Altieri, M.; Nicholls, C. Un método agroecológico rápido para la evaluación de la sostenibilidad de cafetales. Manejo Integr. Plagas Agroecol. 2002, 64, 17-24. Available online: http://repositorio.bibliotecaorton.catie.ac.cr/ bitstream/handle/11554/6866/A2039e.pdf?sequence=1\&isAllowed=y (accessed on 28 April 2019).

8. Sarandón, S.J. El desarrollo y uso de indicadores para evaluar la sustentabilidad de los agroecosistemas. In Agroecología: El Camino Hacia una Agricultura Sustentable; Ediciones Científicas Americanas: La Plata, Argentina, 2002; pp. 393-414. Available online: https://wp.ufpel.edu.br/consagro/files/2010/10/SARANDONcap-20-Sustentabilidad.pdf (accessed on 28 April 2019).

9. Zaldivar, P. Concepciones teórico-metodológicas para el análisis del medio ambiente y la agricultura. In Ciencias Ambientales y Agricultura; Tornero, C.M., López, O.J., Aragón, G.A., Eds.; Publicación especial de la Benemérita Universidad Autónoma de Puebla: Puebla, México, 2006; pp. 1-15.

10. Green, G.P. Sustainability and rural communities. Kans. J. Law Public Policy 2014, 23, $421-436$. Available online: http://law.ku.edu/sites/law.drupal.ku.edu/files/docs/law_journal/v23/10\%20Green_For matted_FINAL.pdf (accessed on 27 April 2019).

11. Vara Sánchez, I.; Cuéllar Padilla, M. Biodiversidad cultivada: Una cuestión de coevolución y transdisciplinariedad. Ecosistemas 2013, 22, 1-5. Available online: https://www.revistaecosistemas.net /index.php/ecosistemas/article/view/758 (accessed on 27 April 2019).

12. Altieri, M.A.; Koohafkan, P. Enduring Farms: Climate Change, Smallholders and Traditional Farming Communities; Third World Network: Penang, Malaysia, 2008; pp. 1-63. Available online: http://www.fao.org/docs/eims/up load/288618/Enduring_Farms.pdf (accessed on 27 April 2019).

13. Brokensha, D.W.; Warren, D.M.; Werner, O. Indigenous Knowledge Systems and Development; University Press of America: Lanham, MD, USA, 1980; p. 473.

14. Marzall, K. Agrobiodiversidade e resiliência de agroecossistemas: Bases para segurança ambiental. Rev. Bras. Agroecol. 2007, 2, 233-236.

15. Martinez Castillo, R. Agroecologías: Atributos de sustentabilidad. InterSedes 2002, 3, $25-45$.

16. Altieri, M.A.; Toledo, V.M. The Agroecological revolution in Latin America: Rescuing nature, ensuring food sovereignty and empowering peasants. J. Peasant Stud. 2011, 38, 587-612. [CrossRef]

17. Sevilla Guzmán, E. De la Sociología Rural a la Agroecología; Icaria Editorial: Barcelona, Spain, 2006; p. 251.

18. Sarandón, S.J. The development and use of sustainability indicators: A need for organic agriculture evaluation. In Proceedings of the XII International Scientific Conference (IFOAM), Mar del Plata, Argentina, 15-19 November 1998.

19. Frausto, O.; Rojas, J.; Santos, X. Indicadores de desarrollo sostenible a nivel regional y local: Análisis de Galicia, España, y Cozumel, México. In Estudios Multidisciplinarios en Turismo; Guevara Ramos, R., Ed.; SECTUR: Ciudad de México, México, 2006; Volume 1, pp. 175-197. Available online: https://cedocvirtual.sec tur.gob.mx/janium/Documentos/9357.pdf (accessed on 24 April 2019). 
20. Loaiza Cerón, W.; Carvajal Escobar, Y.; Ávila Díaz, A.J. Evaluación agroecológica de los sistemas productivos agrícolas en la microcuenca Centella (Dagua, Colombia). Colomb. For. 2014, 17, 161-179. Available online: https://revistas.udistrital.edu.co/ojs/index.php/colfor/article/view/5173/9647 (accessed on 24 April 2019). [CrossRef]

21. Gallopín, G.C. Environmental and sustainability indicators and the concept of situational indicators. A system approach. Environ. Model. Assess. 1996, 1, 101-117. [CrossRef]

22. Harrington, L. Operacionalización del Concepto de Sostenibilidad. Un Método Basado en la Productividad Total; Ponencia del Sexto Encuentro de RIMISP: Campinas, Brasil, 1994.

23. Agosto, P.; Palau, M. Hacia la Construcción de la Soberanía Alimentaria. Desafíos y Experiencias de Paraguay y Argentina; Base Investigaciones Sociale, Equipo de Educación Popular Pañuelos en Rebeldía; CIFMSL: Asunción, Paraguay, 2015; p. 110.

24. Palau Viladesau, T. El movimiento campesino en el Paraguay: Conflictos, planteamientos y desafíos. In Observatorio Social de América Latina (OSAL); CLACSO: Buenos Aires, Argentina, 2005; Volume 16, pp. 35-46.

25. Ortega, G. Mapeamiento del Extractivismo; Base Investigaciones Sociales: Asunción, Paraguay, 2016; pp. 7-8.

26. Guereña, A.; Rojas Villagra, L.; Jára, Y.V.Y. Los Dueños de la Tierra en Paraguay; OXFAM: Asunción, Paraguay, 2016; p. 107.

27. CEPALSTAT_Bases de Datos y Publicaciones Estadísticas. Available online: http://estadisticas.cepal.org/cep alstat/Perfil_Nacional_Social.html?pais=PRY\&idioma=spanish (accessed on 28 April 2019).

28. Ortega, G. Agronegocios vs agricultura campesina: Resistir y producir. In Con la Soja al Cuello 2016. Informe sobre Agronegocios en Paraguay; Palau, M., Ed.; Base Investigaciones Sociales: Asunción, Paraguay, 2016; pp. 18-23.

29. Doughmann, R. La Chipa y la Soja. La Pugna Gastro-Politica en la Frontera Agroexpotadora del Este Paraguayo; Base Investigaciones Sociales: Asunción, Paraguay, 2011; p. 370. Available online: http://biblioteca.clacso.ed u.ar/Paraguay/base-is/20170331031439/pdf_73.pdf (accessed on 27 April 2019).

30. Ortega, G. El dilema de la agricultura campesina durante el gobierno Cartes. In Con la Soja al Cuello 2018. Informe sobre Agronegocios en Paraguay; Palau, M., Ed.; Base Investigaciones Sociales: Asunción, Paraguay, 2018; pp. 18-23.

31. Finnis, E.; Benítez, C.; Candia Romero, E.F.; Aparicio Meza, M.J. Changes to agricultural decision making and food procurement strategies in rural Paraguay. Lat. Am. Res. Rev. 2012, 47, 180-190. Available online: https://www.researchgate.net/publication/236811318_Changes_to_Agricultural_Decision_ Making_and_Food_Procurement_Strategies_in_Rural_Paraguay (accessed on 28 April 2019). [CrossRef]

32. Insfrán Ortiz, A.; Rey Benayas, J.M. La cultura de la restauración de los ecosistemas: Una tarea pendiente en sistemas agrícolas tropicales y en el BAAPA en Paraguay. In Ecología Humana Contemporanea: Apuntes y visiones en la complejidad del desarrollo, 1st ed.; Insfrán Ortiz, A., Aparicio Meza, M.J., Gomes Alvim, R., Eds.; Facultad de Ciencias Agrarias, Universidad Nacional de Asunción: San Lorenzo, Paraguay, 2017; pp. $17-41$. Available online: http://sabeh.org.br/wp-content/uploads/2017/06/ECOLOGIA-HUMANA-CONTEMPORA NEA-internet-red.pdf (accessed on 18 April 2019).

33. Altieri, M.; Nicholls, C.I. Agroecología. Teoría y Práctica Para una Agricultura Sustentable, 1st ed.; Programa de las Naciones Unidas para el Medio Ambiente: Mexico City, Mexico, 2000; p. 250. Available online: htp://www.agro.unc.edu.ar/ \{\}biblio/AGROECOLOGIA2\%5B1\%5D.pdf (accessed on 19 April 2019).

34. FIDA; MERCOSUR; IICA; FAO. Caracterización de la Agricultura Familiar en Paraguay; IICA: Asunción, Paraguay, 2004; p. 30.

35. Barril, A.; Almada, F. La Agricultura Familiar en los Países del Cono Sur; IICA: Asunción, Paraguay, 2007 ; p. 189. Available online: http://orton.catie.ac.cr/repdoc/A2321e/A2321e.pdf (accessed on 19 April 2019).

36. Echenique, J. Caracterización de la Agricultura Familiar; BID-FAO: Santiago de Chile, Chile, 2006.

37. Gasso, V.; Oudshoorn, F.W.; De Olde, E.; Sørensen, C.A. Generic sustainability assessment themes and the role of context: The case of Danish maize for German biogas. Ecol. Indic. 2015, 49, 143-153. [CrossRef]

38. De Olde, E.M.; Oudshoorn, F.W.; Sørensen, C.A.; Bokkers, E.A.; De Boer, I.J. Assessing sustainability at farm-level: Lessons learned from a comparison of tools in practice. Ecol. Indic. 2016, 66, 391-404. [CrossRef]

39. De Olde, E.M.; Sautier, M.; Whitehead, J. Comprehensiveness or implementation: Challenges in translating farm-level sustainability assessments into action for sustainable development. Ecol. Indic. 2018, 85, 1107-1112. [CrossRef] 
40. Food and Agriculture Organization of the United Nations (FAO). SAFA Sustainability Assessment of Food and Agriculture Systems: Guidelines Version 3.0; FAO: Roma, Italy, 2014; p. 253. Available online: http://www.fao.org/3/a-i3957e.pdf (accessed on 28 April 2019).

41. Food and Agriculture Organization of the United Nations (FAO). SAFA Sustainability Assessment of Food and Agriculture Systems: Indicators; FAO: Roma, Italy, 2013; p. 271. Available online: http://www.fao.org/ fileadmin/templates/nr/sustainability_pathways/docs/SAFA_Indicators_final_19122013.pdf (accessed on 28 April 2019).

42. Food and Agriculture Organization of the United Nations (FAO). SAFA Sustainability Assessment of Food and Agriculture Systems: Tool User Manual Version 2.2.40; FAO: Roma, Italy, 2014; p. 20. Available online: http://www.fao.org/3/a-i4113e.pdf (accessed on 28 April 2019).

43. Altieri, M. Agroecologia. In Bases Científicas de la Agricultura Alternativa; Ediciones CETAL: Valparaíso, Chile, 1983; p. 184.

44. Altieri, M. Agroecologia. In Bases Científicas Para una Agricultura Sustentable; Editorial Nordan-Comunidad: Montevideo, Uruguay, 1999; p. 36.

45. Icei. La Agricultura Familiar: Sus Potencialidades y Desafios. Elementos Para la Reflexión; Biblioteca Icei Mercosur: Montevideo, Uruguay, 2011; p. 51.

46. Rojas Villagra, L.; Arrom, C.H.; Ruoti, M.; García, S.; García, C.; Samudio, M. Perspectivas de Sostenibilidad de Comunidades Campesinas en el Modelo de Desarrollo Actual; Informe Técnico; Base Investigaciones-Universidad Nacional de Asunción-CONACYT: Asunción, Paraguay, 2017; p. 122. Available online: https://www.portalguarani.com/2248_luis_rojas_villagra/33791_perspectivas_de_sostenibili dad_de_comunidades_campesinas_en_el_modelo_de_desarrollo_actual_luis_rojas_villagra_ano_2017.html (accessed on 28 April 2019).

47. Mailfert, K. New farmers and networks: How beginning farmers build social connections in France. Tijdschrift Economische Soc. Geogr. 2007, 98, 21-31. [CrossRef]

48. Brunori, G.; Malandrin, V.; Rossi, A. Trade-off or convergence? The role of food security in the evolution of food discourse in Italy. J. Rural Stud. 2013, 29, 19-29. [CrossRef]

49. Belasco, W. Food and the counterculture: A story of bread and politics. In The Cultural Politics of Food and Eating; Watson, J., Caldwell, M., Eds.; Blackwell: Oxford, UK, 2005; pp. 217-234.

50. Merlo, V. Voglia di Campagna: Neoruralismo e Città; Città Aperta Edizioni: Troina, Italy, 2006; p. 285.

51. Orria, B.; Luise, V. Innovation in rural development: "neo-rural" farmers branding local quality of food and territory. IJPP Ital. J. Plan. Pract. 2017, 7, 1-29. Available online: https://air.unimi.it/retrieve/handle/2434/598461/1093923/Orria\%20B.\%2C\%20Luise\%20V.\%2C\%20Inn ovation\%20in\%20rural\%20development\%3A\%20\T1 \textquotedblleftneo-\%20rural \T1\textquotedblrigh t\%20farmers\%20branding\%20local\%20quality\%20of\%20food\%20and\%20territorypdf.pdf (accessed on 28 April 2019).

52. Vargas Lehner, F. Evaluación de la Sustentabilidad de Agroecosistemas en Tres Comunidades Mbya Guarani del Departamento de Caaguazù: Una Propuesta Metodológica; Carrera de Ingeniería en Ecologia Humana, Facultad de Ciencias Agrarias, Universidad Nacional de Asunción: Asunción, Paraguay, 2008.

53. Godoy, M. Condiciones de vida y estructuras domésticas campesinas del grupo doméstico guaraní a la familia nuclear paraguaya. In Pasado y Presente de la Realidad Paraguaya; La Cuestión Agraria, CEPS: Asunción, Paraguay, 2001; Volume 3.

54. Food and Agriculture Organization of the United Nations (FAO). La Estrategia de la FAO Sobre el Cambio Climático; FAO: Roma, Italy, 2007; Available online: http://www.fao.org/3/a-i7175s.pdf (accessed on 28 April 2019).

55. Vicente, C.A. La agricultura campesina enfría el planeta. In Con la Soja al Cuello 2016. Informe sobre Agronegocios en Paraguay; Palau, M., Ed.; Base Investigaciones Sociales: Asunción, Paraguay, 2016; pp. 84-87.

56. Apipé, G. Paraguay importa el 6,2\% de agroquímicos vendidos en el mundo. In Con la Soja al Cuello 2018. Informe sobre Agronegocios en Paraguay; Palau, M., Ed.; Base Investigaciones Sociales: Asunción, Paraguay, 2018; pp. 32-35.

57. Apipé, G. A medida que aumenta el uso de transgénicos, más veneno se verte sobre los campos de cultivo. In Con la Soja al Cuello 2017. Informe sobre Agronegocios en Paraguay; Palau, M., Ed.; Base Investigaciones Sociales: Asunción, Paraguay, 2017; pp. 14-17. 
58. Graeub, B.E.; Chappell, M.J.; Wittman, H.; Ledermann, S.; Kerr, R.B.; Gemmill-Herren, B. The state of family farms in the world. World Dev. 2016, 87, 1-15. [CrossRef]

59. Casalì, P.; Velazquéz, M. Paraguay. Panorama de la Protección Social: Diseño, Cobertura y Financiamiento, 1st ed.; Organización Internacional del Trabajo: Santiago, Chile, 2016.

60. Riquelme, Q. Políticas de Estado y agricultura campesina. In Con la Soja al Cuello 2016. Informe sobre Agronegocios en Paraguay; Palau, M., Ed.; Base Investigaciones Sociales: Asunción, Paraguay, 2016; pp. 46-49.

61. Riquelme, Q. Programas y proyectos para la agricultura campesina. In Con la Soja al Cuello 2017. Informe sobre Agronegocios en Paraguay; Palau, M., Ed.; Base Investigaciones Sociales: Asunción, Paraguay, 2017; pp. 30-33.

62. Foro Internacional sobre Agroecología (FIA). Declaración del Foro Internacional sobre Agroecología; Nyéléni, Mali. 27 February 2015. Available online: https://viacampesina.org/es/declaracion-del-foro-internacional-deagroecologia/ (accessed on 14 May 2019).

63. Pacheco, M.E.L. Em defesa da agricultura familiar sustentável com igualdade de gênero. In Perspectivas de Gênero: Debates e Questões Para as ONGs; GT Gênero-Plataforma de Contrapartes Novib/SOS Corpo; Gênero e Cidadania: Recife, Brazil, 2002; pp. 138-161.

64. Food and Agriculture Organization of the United Nations (FAO). L'agro-Ecologia può Aiutare a Migliorare la Produzione Alimentare Mondiale. Available online: http://www.fao.org/news/story/it/item/1113664/icode/ (accessed on 28 April 2019).

65. Dirección General de Estadísticas, Encuestas y Censos de Paraguay (DGEEC). Principales Resultados EPH 2013. Encuesta Permanente de Hogares; DGEEC Publicaciones: Fernando de la Mora, Paraguay, 2014; p. 191. Available online: https://www.ilo.org/surveydata/index.php/catalog/332/download/3416 (accessed on 28 April 2019).

(C) 2019 by the authors. Licensee MDPI, Basel, Switzerland. This article is an open access article distributed under the terms and conditions of the Creative Commons Attribution (CC BY) license (http://creativecommons.org/licenses/by/4.0/). 